\title{
Governing through Killing: The War on Drugs in the Philippines
}

\author{
David T. JOHNSON* \\ University of Hawaii, Manoa, Hawaii \\ Jon FERNQUEST** \\ University of Hawaii, Manoa, Hawaii
}

\begin{abstract}
This article focuses on the war on drugs in the Philippines in order to explore issues related to extra-judicial killing, which remains common in many countries that have abolished the death penalty and in many more that retain it but seldom carry out judicial executions. In the first year of Rodrigo Duterte's presidency (2016-17), thousands of people were killed by police or by vigilantes who were encouraged to prosecute his war on drugs. At a time when democracy is in retreat in many parts of the world, this case illustrates how popular harsh punishment can be in states that have failed to meet their citizens' hopes for freedom, economic growth, and security.
\end{abstract}

Keywords: extra-judicial killing, capital punishment, homicide, penal populism, public opinion, impunity

\section{INTRODUCTION}

Please feel free to call us, the police, or do it yourself if you have the gun - you have my support. Shoot [the drug dealer] and I'll give you a medal (President elect Rodrigo Duterte, 6 June 2016). ${ }^{1}$

Hitler massacred three million Jews .... There's three million drug addicts. There are. I'd be happy to slaughter them (President Rodrigo Duterte, 30 September 2016). ${ }^{2}$

In the name of eliminating drug crime, President Rodrigo Duterte has plunged the Philippines into a nightmare of brutal slaughter. The police say that since July 1 [2016], they have killed more than 2000 people suspected of drug-related crimes. In addition, more than 3500 homicides remain unsolved, many at the hands of unknown vigilantes. ${ }^{3}$

* Professor of Sociology at the University of Hawaii at Manoa

** $\mathrm{PhD}$ student in the Department of Sociology at the University of Hawaii at Manoa. The authors thank all the Philippine journalists whose reporting made this article possible and Professor Patricio Abinales (University of Hawaii at Manoa), who provided much helpful advice.

1. Kaiman (2016a).

2. Lasco (2016).

3. New York Times (2016). 
Labels such as "state killing" and "the killing state" are often used to describe the legally permitted judicial killing that occurs in systems of capital punishment. ${ }^{4}$ But states kill extra-judicially too, and sometimes the scale so far exceeds the number of judicial executions that death-penalty reductions and abolitions seem like small potatoes. ${ }^{5}$

This article focuses on extra-judicial killing in the Philippines during the first year and a half of President Rodrigo Duterte's war on drugs (June 2016-January 2018), for three reasons. First, the Philippines is a large country whose systems of punishment have seldom been studied. With more than 100 million people, it is the thirteenth most populous country in the world, and it has more people than any country in Europe. Second, extra-judicial killing in the Philippines has attracted much attention because of its large scale and the impunity enjoyed by its perpetrators. In January 2018, Philippine police acknowledged that approximately 4,000 suspected drug users or sellers had been killed in the war on drugs, while Human Rights Watch put the number at $12,000^{6}$ and Philippine human rights advocates claimed it was more than $16,000 .^{7}$ Despite thousands of slayings, only a handful of investigations have occurred, and not a single government official has been convicted. Third, we aim to focus attention on extra-judicial killing because it a neglected subject in scholarship on punishment. By our count, the journal Punishment \& Society published 35 articles and 20 book reviews about capital punishment in its first 19 years, but only two articles on extra-judicial killing. ${ }^{8}$ There has been a huge increase in the range and depth of scholarly work on the punishment of offenders who violate the criminal law. ${ }^{9}$ There is also a growing literature on the so-called "justice cascade"-how offenders against human rights norms are increasingly punished and called to account. ${ }^{10}$ But these two bodies of work "barely overlap"11 and both of them neglect the ways in which politicians, police, and members of the military frequently construe their own violence as morally justified acts of punishment and social control. ${ }^{12}$ For these reasons, we want to encourage research that will "expand criminology's domain" to include a subject that is interesting, important, and marginalized. ${ }^{13}$ In studies of law and society, too, extra-judicial killing has largely flown under the radar. ${ }^{14}$

Some analysts argue that the "abolition of capital punishment in all countries of the world will ensure that the killing of citizens by the state will no longer have any legitimacy and so even more marginalize and stigmatize extra-judicial executions." ${ }^{\prime 15}$ Others claim that the abolition of capital punishment is "one of the great, albeit unfinished, triumphs of the

\footnotetext{
4. Sarat (1999).

5. Johnson \& Zimring (2009), pp. 443-51.

6. Villamor (2018c).

7. Romero (2017).

8. The two articles on extra-judicial killing are on the Rwandan genocide and on populist punitiveness in South Africa; see Drumbl (2000); Super (2016).

9. Garland (2018).

10. Sikkink (2011).

11. Savelsberg (2018).

12. Black (1983); Robinson \& Robinson (2018).

13. LaFree (2006).

14. In the twentieth century, government actors were responsible for an estimated 180 million human killings in the world, which is about ten times more than the number of victims of violence in civil society; Savelsberg (2017), p. 86; see also Kaufman \& Fagan (1981); Hagan \& Rymond-Richmond (2009).
}

15. Hood \& Hoyle (2008), p. 6. 
post-Second World War human rights movement" 16 and that "abolition is a prerequisite for any regime aspiring to dissociate itself from those dark forces known for their hostility to democracy, equality and human dignity."17 This article suggests that these views are too sanguine. What is happening in the Philippines-thousands of executions in a country without capital punishment-represents a pattern that has been seen before and that will be seen again in polities with weak law, strong executives, and fearful and frustrated citizens. State killing often survives and sometimes thrives after capital punishment is abolished (see Mexico, Brazil, Nepal, and Cambodia). And in countries where capital punishment has not been abolished, extra-judicial executions have frequently been carried out after the number of judicial executions fell to near zero (as in Bangladesh, India, and Indonesia).

The rest of this article proceeds as follows. First, we summarize state killing in the Philippines—judicial and extra-judicial—from the time Ferdinand Marcos became president in 1965 until 2016, when Duterte was elected. During this half-century, capital punishment rose and fell while extra-judicial executions remained a regular feature of Philippine society. Then we describe extra-judicial killing during the first year of Duterte's war on drugs and show its continuity with the practices of a "death squad" that was organized and orchestrated by Duterte when he was mayor of the city of Davao in the southern part of the country. In Section 4, we explain extra-judicial killing in the Philippines by presenting three main causes: the problem of impunity in Philippine criminal justice, which has frustrated large segments of the public; a Philippine form of penal populism in which governing through killing remains popular even though it is ineffective as crime control; and a form of democratic underdevelopment that is perpetuated by a narrow elite who rule Philippine society for their own benefit. In Section 5, we briefly summarize major developments in the first half of the second year of Duterte's presidency, including a new offensive in his war on drugs, a pause in extra-judicial killing that was precipitated by public protests over the murder of a young man in Manila, and an announcement that Philippine police would conduct their renewed crackdown on drugs in accordance with a new set of guidelines designed to encourage compliance with laws and human rights norms. In the concluding section, we suggest five lessons that students of punishment and society should learn from this casestudy. Foremost among them is the possibility that the decline of democracy in many parts of the world may encourage tolerance of executions in states that have capital punishment —and in some states that do not.

\section{STATE KILLING IN THE PHILIPPINES BEFORE DUTERTE}

The Philippines has abolished the death penalty twice: in 1987, after dictator Ferdinand Marcos fell from power, and then again (after the death penalty was reinstated in 1993) in 2006, following a push by the Roman Catholic Church and President Gloria Macapagal Arroyo. Under President Duterte in 2016-17, there was an effort in the Philippine Congress to resurrect the death penalty again ${ }^{18}$ but, as of this writing (January 2018), no law had been enacted.

\footnotetext{
16. Hodgkinson (2004), p. 1.

17. Schabas (2004), p. 62; Schabas (2002), pp. V and 377.

18. Gil (2017).
} 
Under Marcos, who ruled the country from 1965 to 1986, the Philippines carried out 31 judicial executions and at least 3,000 extra-judicial executions-a ratio of 1 to $100 .{ }^{19}$ Even under martial law (September 1972-January 1981), there were only 12 judicial executions in the Philippines, and there were no judicial executions at all during the last nine years of Marcos's rule (1977-86). After Marcos was overthrown by the People Power Movement, the Constitution of 1987 abolished capital punishment "unless for compelling reasons involving heinous crimes, the Congress hereafter provides for it." In 1993, the Philippine Congress reinstated the death penalty by passing one of the most expansive capital statutes in Asia and soon the Philippines had one of the largest death rows in Asia: more than 1,200 people were sentenced to death under the new death-penalty law, but only seven were executed. All were men and all were lethally injected between February 1999 and January 2000, during the administration of President Joseph Estrada, who was driven from power by a second "People Power" movement and subsequently convicted of plunder and sentenced to life in prison (later he was pardoned by President Arroyo). On Easter Sunday in 2006, President Arroyo commuted more than 1,200 death sentences in one of the largest mass death sentence commutations the world has ever seen. Two months later, she signed a Bill into law that abolished capital punishment in the Philippines for the second time in 20 years. The Bill had easily passed both chambers of Congress: 120 to 20 in the House and 16 to 0 in the Senate. ${ }^{20}$

From 1993 to 2006, while death sentences were common and judicial executions were rare, extra-judicial executions continued to occur frequently in the Philippines, as they had throughout much of the twentieth century. ${ }^{21}$ For example, the non-governmental organization (NGO) Karapatan found that, from 2001 to 2006, 819 people were victims of "extra-judicial, summary, or arbitrary execution" under the Arroyo government-an average of 137 non-judicial state killings per year during the first half of her presidency. ${ }^{22}$ Arroyo pushed for the abolition of capital punishment, but she also stressed her own prerogatives of power, as when she asserted in her state of the nation address in 2007 that "From where I sit, I can tell you, a President is always as strong as she wants to be." ${ }^{23}$ After leaving office in 2010, Arroyo was arrested on charges of plunder. In 2016, the Supreme Court acquitted her by a vote of 11 to 4 .

Extra-judicial killings in the Philippines seemed to decline under Arroyo's successor, President Benigno Acquino III, but at least 300 leftist activists, human rights defenders, and alleged supporters of communist rebels were killed during his six-year term (2010-16). Those killings rarely resulted in criminal prosecution. Near the end of Acquino's presidency, the deputy Asia director of Human Rights Watch warned that "while the number of serious violations has declined during Aquino's administration, ongoing killings of prominent activists and the lack of successful prosecutions mean there's nothing to prevent an upsurge of abuses in the future." 24 This warning would prove to be prescient.

\footnotetext{
19. Fenton (2017a).

20. Johnson \& Zimring, supra note 5, pp. 103-45.

21. Abinales \& Amoroso (2017); Parreno (2011); McCoy (2009).

22. Hilbay (2009), p. 2.

23. Ibid., p. 1.

24. Arceo (2016), emphasis added.
} 


\section{EXTRA-JUDICIAL KILLING IN DUTERTE'S WAR ON DRUGS}

It is impossible to know how many people have been killed by police and other government officials in the first year of Duterte's war on drugs, because the Philippine state is neither transparent nor consistent about how often it kills extra-legally. ${ }^{25}$ There also are different degrees of state involvement, from (1) tolerating, condoning, and encouraging the killing of drug users and sellers, to (2) the fiction of buy-bust operations in which the targets of a sting resist arrest and are killed in a shoot-out, to (3) cold-blooded assassination as an act of governmental terrorism. ${ }^{26}$ Moreover, some ordinary murders are staged to look like extra-judicial executions in order to prevent police investigation into the killing, thereby further complicating efforts to count. In many cases, there is little real distinction between a buy-bust killing and an extra-judicial one. ${ }^{27}$ If the victim did not have a gun, one can be given to him after he is killed-and it frequently is. ${ }^{28}$

Although accurate counts of extra-judicial killing are hard to come by, even the lowest estimates are large, and so are the figures provided by state officials. According to the Philippine National Police, as of 30 June 2017 (one year after Duterte took office), nearly 5,000 drug suspects had been killed, including 3,151 in reported gun battles with the police, and 1,847 others had been killed in drug-related attacks by masked gunmen on motorcycles and other vigilante assailants. ${ }^{29}$ Non-governmental sources report much higher death tolls. According to one, in the first two months after Duterte became president, over 7,000 people were killed by police or by vigilantes encouraged to prosecute the war on drugs. ${ }^{30}$ That would be more than 1,000 times the number of people judicially executed in the 13 years (1993-2006) that the Philippines had capital punishment before it abolished it the second time. Ten months into Duterte's six-year presidency, the New York Times published an editorial reporting the number of dead at more than 9,400 - an average of 32 per day. This is approximately three times more extra-judicial executions than the world's leading judicial executing state (the People's Republic of China, with a population 13 times that of the Philippines) executed in $2016 .{ }^{31}$ Even by the most conservative estimates, the frequency of

25. The best analysis of the difficulties counting the number of extra-judicial killings has been provided by the Philippine Center for Investigative Journalism, which reported that "the government's drug war narrative so far has not only been bloody, it has also been blurry. Although government officials have not denied that lives have been lost in the anti-drug campaign, they have yet to explain its narrative that is crowded with constantly changing concepts and terms, even as it is decked in numbers inflated then deflated and later inflated again. Indeed, it is a narrative defined from a war waged mainly as a police operation, its 'accomplishments' or success pegged on an ever-lengthening trail of bodies and victims, but with no certain answers for whence or how it should end, and bereft of solid baselines and firm targets"; see Philippine Center for Investigative Journalism (2017).

26. Kaufman \& Fagan, supra note 14; Belur (2010).

27. Fenton (2017b).

28. After a person is killed in Duterte's war on drugs, the police routinely claim that they fired their guns only because they were fired upon first. Policing in the Philippines is dangerous. In the 18 months from July 2016 through December 2017, 86 police officers were killed and 226 were wounded in a Philippine police force with approximately 170,000 officers. The probability of a police officer in the Philippines being killed is thus about 4.5 times higher than the probability of a police officer being killed in the US; see Zimring (2017), p. 94. However, a Reuters review of 51 drug-related shooting incidents in Manila found that police killed a total of 100 suspects and wounded only three-two of whom played dead; see Baldwin (2016). This lopsidedly lethal ratio suggests that Philippine police are either amazingly accurate shooters or else they are determined to kill the citizens they target in the war on drugs; see also Special Report (2017).

29. Gomez \& Cerojano (2017).

30. Bueza (2017).

31. The source for this estimate of 9,400 extra-judicial executions is Filipino lawyer Jude Josue Sabio, who submitted it to the ICC when he formally asked the ICC to charge Duterte and 11 other officials with mass murder and crimes against humanity. New York Times (2017a); New York Times (2017b). 
Table 1. Drug-related killings reported in the first year of the Philippine war on drugs

\begin{tabular}{llccc}
\hline Source & \multicolumn{1}{c}{ Time period } & Killings & By police & By other \\
\hline Police & $7 / 1 / 2016$ to $1 / 31 / 2017$ & 7,080 & - & - \\
Police & $7 / 1 / 2016$ to $6 / 30 / 2017$ & 4,998 & - & - \\
Rappler & $7 / 1 / 2016$ to $4 / 2 / 2017$ & 7,080 & - & - \\
AI & $7 / 1 / 2016$ to $1 / 21 / 2017$ & 7,025 & - & - \\
HRW & $7 / 1 / 2016$ to $1 / 31 / 2017$ & 7,080 & - & - \\
ABS-CBN & $7 / 1 / 2016$ to $3 / 31 / 2017$ & 9,432 & 2,692 & - \\
New York Times & $7 / 1 / 2016$ to $4 / 25 / 2017$ & 9,400 & - & - \\
Bloomberg & $7 / 1 / 2016$ to $6 / 30 / 2017$ & 5,000 & 3,151 & 1,847 \\
ABC News & $7 / 1 / 2016$ to $6 / 30 / 2017$ & 5,200 & 3,000 & 2,000
\end{tabular}

Sources: Philippine National Police, www.pnp.gov.ph; Rappler, 2 March 2017; Amnesty International (AI) (2017); Human Rights Watch (HRW) (2017); ABS-CBN, 5 May 2017; New York Times, 25 April 2017; Bloomberg, 30 June 2017; ABC News, 24 July 2017.

extra-judicial killing in Duterte's war on drugs is far higher than the frequency of extrajudicial killing under the martial law imposed by Marcos in the 1970s (see Table 1). ${ }^{32}$

After Duterte became president, he began gathering the names of drug suspects from local police and elected officials. This is called a "watch list" and there are (in Duterte's various tellings) anywhere from 600,000 to 1 million names on it, including at least 6,000 police officers, 5,000 local village leaders, and 23 mayors. ${ }^{33}$ Most of the people on the list have been targeted by "Operation Knock \& Plead" (Oplan Tokhang), which resulted in surrendering of 687,000 people across the country to police, ${ }^{34}$ further burdening an already overburdened criminal justice system. ${ }^{35}$ People who do not surrender are more likely to be targeted for extra-judicial execution, and many of the people who do surrender are made to sign a form pledging to stay off drugs. As reported by one man who was addicted to methamphetamines and who surrendered on the day Duterte took office, the form he signed said: "If you're caught the first, second, and third time, there are warnings and conditions. If you're caught a fourth time, we'll have nothing to do with whatever happens to you."36

The war on drugs also employs "mass interrogations" (sona) in which tens or hundreds of (mostly poor) men are called out of their homes, lined up, arrested, and questioned. Some of them end up dead. ${ }^{37}$

There is apparently "no certain or easy way to get off Duterte's list," 38 even for those who are powerful and well connected. Consider three examples. On 28 October 2016, a southern

\footnotetext{
32. For death tolls and related statistics based on data provided by the Philippine National Police as of January 2018 , those numbers had not been updated since April 2017. As of 30 January 2017, the Rappler web site reported that there had been 7,080 people killed in the war on drugs in the preceding seven months; Bueza, supra note 30. After Duterte became president, the Inquirer published an updated "kill list" until 16 February 2017, when it stopped because the war on drugs was temporarily halted. According to the list, there were at least 1,104 killings by police and 1,022 killings by unknown hitmen as of 16 February 2017; see Inquirer (2017).

33. Symmes (2017).

34. Chen (2016).

35. Jones (2016).

36. Kaiman (2016b).

37. Syjuco (2017).

38. Symmes, supra note 33 .
} 
mayor named Samsudin Dimaukom was stopped at a checkpoint by police who claimed Dimaukom opened fire first. The mayor and all nine of his aides and guards were killed, and no police were injured. Twelve days later, on 5 November, police entered the jail cell of Albuera mayor Rolando Espinosa Sr, who had implicated police in the drug trade. Espinosa and his cellmate (Raul Yap) were shot dead in what the National Bureau of Investigation and a Senate investigation subsequently found to be murder. ${ }^{39}$ Twenty-four police were arrested for these two killings, including Police Superintendent Marvin Marcos, but eight months later they were all reinstated on Duterte's orders, perhaps because the president feared that "these policemen might rat out on him for what they know about his involvement in the Espinosa murder."40 On 30 July 2017, Ozamiz city mayor Reynaldo Parojinog, his wife, brother, sister, and 11 of their security personnel were killed after they allegedly opened fire on police-and after police had disabled CCTV in the mayor's home and three nearby residences during their pre-dawn raid. No police were killed or injured in the encounter. Mayor Parojinog had denied any ties to illegal drugs, but he was widely believed to be a "narco-politician" involved in robbery, extortion, illegal gambling, and drug trafficking. Since some Ozamiz residents regarded the mayor's ruling clan as Robin Hoods, there was mourning in the city for some of those who were slain but, outside the city, the most common reactions to the killings seemed to be "good riddance" and "why did it take so long?". 41 To Duterte's supporters, the elimination of politicians such as Dimaukom, Espinosa, and Parojinog demonstrates their president's resolve to reform a country that some call "a gangster's paradise." 42

Duterte has made many pronouncements about how to prosecute the war on drugs. While campaigning for the presidency, he promised to rid the country of crime and drug use within 3-6 months. After he was elected, he compared himself to Hitler and said he would be "happy to slaughter 3 million drug addicts." ${ }^{, 43}$ On numerous occasions, he has publically encouraged police to "go ahead and kill them [drug users]" and promised to protect police killers from legal accountability. He has said: "Rich or poor, I do not give a shit. My order is to destroy." 44 He has declared: "I don't care about human rights, believe me. There is no due process in my mouth." 45 He has promised that "the fish will grow fat" from the bodies dumped in Manila Bay. ${ }^{46}$ He has taken aim at lawyers who defend drug suspects, threatening to include them in his drug war. He encouraged 19 police officers implicated in the death of an alleged drug lord to plead guilty so that he could pardon them. ${ }^{47}$ And when US President Barack Obama cancelled a meeting with Duterte out of concerns over extra-judicial killing in the Philippines, Duterte called him a "son of a whore," said "we have long ceased to be a colony," and stressed that he is "only answerable to the Filipino people who elected me president." 48

\footnotetext{
39. Ibid.

40. Tordesillas (2017).

41. Pamintuan (2017a).

42. Pamintuan (2017b).

43. Lasco, supra note 2.

44. Iyengar (2016).

45. Ibid.

46. Symmes, supra note 33.

47. Weiss (2017).

48. Gayle (2016).
} 
In addition to Duterte's provocative pronouncements, there are other performative aspects of extra-judicial killing in the Philippines. ${ }^{49}$ Abundant theatricality accompanies many things in the country, from karaoke and religious processions to the soap operas and melodramas on TV. ${ }^{50}$ So, too, in the war on drugs. Corpses are found bearing cardboard signs that say "I am a pusher" or "I am a drug user, don't be like me." Victims have their heads mummified in packing tape, with cartoon expressions drawn on their faces. Dead bodies are posed in positions and places to maximize public viewing. And photojournalists who cover extra-judicial killing stage their own performances by chasing "The Shot"—an image powerful enough to capture the crackdown's human costs. But in the first year of the war on drugs, even the most moving images of death did little to fuel public outrage. In fact, the crowds that form around victims of extra-judicial killing are "often festive, treating the whole scene as if it were entertainment." 51 People laugh, mug for the cameras, make jokes, and take bets on whether they knew the victim. In some ways, the rompish atmosphere is reminiscent of public hangings in eighteenth-century Europe ${ }^{52}$ and lynching scenes in the Jim Crow south. ${ }^{53}$

For his part, Duterte has frequently accused the media of "doing dramatics" and practising "yellow journalism" (reporting that relies on sensationalistic headlines instead of real research). He also has alleged that critical journalists are being paid by his enemies-and perhaps even by drug lords. ${ }^{54}$ Since Marcos was overthrown in 1986, more than 170 journalists have been assassinated in the Philippines, and Duterte apparently believes many of them deserved to die. In a press conference shortly after he was elected, he said: "Most of those [journalists] killed, to be frank, have done something. You won't be killed if you don't do anything wrong. Just because you're a journalist you are not exempted from assassination if you're a son of a bitch." 55

When one of Duterte's fiercest critics, Senator Leila De Lima, called for an investigation of extra-judicial killing, Duterte threatened to throw her in jail—and then he had her arrested on three counts of drug trafficking with prisoners in the New Bilibid Prison on the outskirts of Manila, which holds more than 20,000 inmates. ${ }^{56}$ She was jailed based on the testimony of prisoners, with no evidence of drugs. She is ineligible for bail, and Duterte has said that she should "just hang herself" and that he expects to "see her in hell." ${ }^{, 57}$ Duterte also revealed details of an affair between De Lima and her bodyguard/driver, who allegedly collected money from inmates to fund her senatorial campaign while she was secretary of the Department of Justice. Her attorneys have filed a case with the Supreme Court to prevent

\footnotetext{
49. Brown (2009).

50. Symmes, supra note 33 .

51. Rodis (2017).

52. Spierenburg (2008).

53. Garland (2005).

54. Kaiman, supra note 1.

55. According to the Committee to Protect Journalists, in the decade between August 2006 and August 2016, 41 journalists were "killed with complete impunity" in the Philippines, giving the country the fourth worst record for assassinated journalists in the world, behind Somalia, Iraq, and Syria. At least 34 of those journalists were killed in the Maguindanao Massacre of 23 November 2009, which may be the single deadliest event for journalists in history. See Witchel (2016).

56. Villamor (2017d); Santos (2017); Jones, supra note 35.

57. Ibid.
} 
Duterte from further degrading her dignity. It is the first case to challenge a sitting president's behaviour as "psychological violence, sexual harassment, and slut-shaming against women." 58 One of her lawyers has wondered: "If this can happen to a senator, what more to an ordinary Filipino?" 59 Duterte has threatened and harassed other prominent women as well, including Ombudsman Conchita Carpio Morales, Rappler editor Maria Ressa, and Chief Justice of the Supreme Court Maria Lourdes Sereno.

Duterte has been called the "Donald Trump of the Philippines." 60 Like his American counterpart (who hosted The Apprentice on NBC TV for 14 seasons), Duterte has a nose and knack for publicity. He also has his own TV shows. In Davao, From the Masses, for the Masses aired every Sunday on local TV while Duterte was mayor of that city, and the president recently launched his own national TV show with a similar name on government-owned People's Television. The aim of both shows is "to communicate the policies of the Duterte administration to the masses" straight from the president himself. ${ }^{61}$ If the new TV show is like the old one, Duterte will not only discuss his government's programmes and policies; he will announce the names of people suspected to be involved in the drug trade - and some of them will then be killed.

Duterte ran for president against four other candidates and won handily, with $39 \%$ of the vote (more than $15 \%$ ahead of his nearest competitor). After he was elected, Time magazine featured a smiling Duterte on its cover under the title "The Punisher." He also has been called "Duterte Harry." 62 Despite criticism at home and abroad of the extra-judicial killing that has been perpetrated in his war on drugs, opinion polls in his first year consistently showed that he was liked, trusted, and supported by large majorities of the Filipino people (see Table 2). In fact, public support for Duterte is higher than for any previous Filipino president. His strongest support is among the poor, who also comprise the vast majority of victims in his war on drugs, ${ }^{63}$ but he is also supported by majorities of the middle and upper classes. ${ }^{64}$ In the last quarter of 2016, Duterte's approval and trust ratings were both above $80 \%{ }^{65}$ and, in April 2017, 78\% of Filipino adults said they were satisfied with the government's crackdown on drugs, while only $12 \%$ said they were dissatisfied (see Table 2). ${ }^{66}$

But there is also ambivalence in public attitudes toward Duterte's war on drugs. In survey results released in December 2016, for example, $85 \%$ of respondents said they were satisfied with the administration's campaign against legal drugs and $88 \%$ said that the drug problem had declined after Duterte became president, but 69\% considered extra-judicial killing a serious problem, and $78 \%$ worried that they, or someone they know, would become a victim of extra-judicial killing. ${ }^{67}$ These mixed feelings suggest that public opinion on this subject

\footnotetext{
58. Ibid. note 55 .

60. Symmes, supra note 33 .

61. de Guzman (2017).

62. Curato (2016a).

63. Kaiman, supra note 1; Mogato \& Baldwin (2017).

64. Heydarian (2018).

65. Ranada (2017).

66. Cupin (2017).

67. Abinales \& Amoroso, supra note 21, p. 344.
}

59. Some analysts think Duterte has a personal vendetta against De Lima. In 2009, when he was mayor of Davao, De Lima was head of the Commission on Human Rights, which investigated Duterte's involvement in extra-judicial killings in that city. De Lima admits berating him then, and she believes he has never forgotten it. Witchel, supra 
Table 2. Public approval ratings for President Rodrigo Duterte, July 2016June 2017

\begin{tabular}{lc}
\hline Date & Rating \\
\hline July 2016 & $91 \%$ \\
October 2016 & $86 \%$ \\
December 2016 & $83 \%$ \\
March 2017 & $76 \%$ \\
June 2017 & $82 \%$ \\
Average & $84 \%$ \\
\hline
\end{tabular}

Source: Pulse Asia Research public opinion polls as reported in Rappler, www.rappler.com.

Note: Pulse Asia Research's Ulat ng Bayan survey is a nationwide public opinion poll for the Philippines that measures public approval of the Philippine president's performance.

will vary considerably depending on the context and the wording of questions. ${ }^{68}$ The ambivalence also reflects value conflicts within individuals who want to enjoy the benefits of crime control without being plagued by the knowledge or guilt that people are being killed extra-judicially.

Duterte has been called "a liberal's worst nightmare" $" 69$ and a "serial killer president" in the country where he rules, he remains highly popular. His supporters, who are sometimes pejoratively called "Dutertardes," are not simply ignorant prey for demagoguery and propaganda. ${ }^{71}$ They sincerely believe he cares about their concerns ${ }^{72}$ and they are pleased with his policies and moved by his stories. ${ }^{73}$ Public support for Duterte is also rooted in the anger, frustration, and helplessness that people feel about the dysfunctions of Philippine criminal justice. As long as they believe the justice system is broken, they seem likely to support the president's heavy-handed approach to threats to the social order. ${ }^{74}$

In the courtroom of public opinion, the war on drugs is believed to be working even after Duterte suspended it for a month early in 2017 (30 January-27 February) following the revelations that Filipino police had kidnapped and strangled a South Korean businessman named Jee Ick-joo and then flushed his cremated ashes down a toilet in the national police headquarters. ${ }^{75}$ This killing apparently occurred during an effort to obtain a USD 100,000 ransom from Jee's family. National police chief Ronald dela Rosa said this death was not part of the war on drugs, but critics claimed police had been emboldened by Duterte's promise to

\footnotetext{
68. Zimring (2003), p. 12.

69. Demick (2016).

70. Gonzales (2016).

71. Heydarian, supra note 64

72. Curato (2017b).

73. Barrera (2017).

74. Pamintuan, supra note 41

75. After this brief moratorium on extra-judicial killing, the war on drugs was resumed in two stages: first with small drug-enforcement task forces (deployed on 27 February 2017) and then more aggressively when "Oplan Double Barrel Alpha Reloaded" was launched (on 6 March 2017). The "Double Barrel" phrase represents a drug policy that is supposed to be aimed in two directions simultaneously, with one barrel directed upwards at high-level drug traffickers and the other pointed downwards at poor drug sellers and users. In reality, however, most victims of extra-judicial killing are poor. One study found that more than half of victims were unemployed and that men outnumbered women by a ratio of 14:1; see Abinales \& Amoroso, supra note 21, p. 343.
} 
shield from prosecution those involved in the crackdown. ${ }^{76}$ Following Jee's murder, police chief dela Rosa was neither replaced nor reprimanded, and Duterte made many statements in support of the man who also had served as chief of police in Davao when Duterte ruled that city. A survey at the midpoint of Duterte's first year in office found that $88 \%$ of Filipino adults perceived a decrease in the country's drug problem since he became president ${ }^{77}$ and, according to official statistics, crime in the country dropped by more than a quarter in Duterte's first year. Drug abuse is a serious concern to many Filipinos. In a country that has failed to fix the circumstances that foster demand for drugs, Duterte's harsh approach is widely considered a necessary evil. ${ }^{78}$

The war on drugs that commenced in 2016 replayed on a national scale many of the policies that Duterte promoted while he was mayor of Davao (population 1.6 million) on the island of Mindanao. Duterte was elected mayor of that city seven times (he has never lost an election) and he served in the position for a total of 22 years. During his mayorship, the so-called Davao Death Squad killed at least 1,400 persons-an average of five people per month. Not a single person was successfully prosecuted for any of those killings. Duterte has been called "the Death Squad mayor",79 and he has done little to deny the appropriateness of the appellation. While running for president, he declared: "Am I the Death Squad? Yes." He also confessed to killing three kidnappers in Davao in 1988, the first year he was mayor. As he told the BBC: "I don't know how many bullets from my gun went inside their bodies. It happened, and I said, I cannot lie about it." ${ }^{80}$ Some analysts believe there "has yet to be actionable evidence linking Duterte to the killings beyond his tolerance, if not support, for summary execution" ${ }^{, 1}$ but, in our view, the available evidence strongly suggests that he organized the Davao Death Squad and ordered many of the extra-judicial killings it committed.

Two members of the Davao Death Squad have publicly described their own participation in extra-judicial killings while Duterte was mayor of that city. In September 2016, 57-year-old Edgar Matobato testified in the Philippine Senate that he had killed approximately 50 people in Davao, many at the direction of Duterte. And, in a press conference at the Philippine Senate in February 2017, a retired policeman named Arthur Lascanas confessed to killing 200 people while he was on the Davao Death Squad. Lascanas also reported that members of the Squad were typically paid 20,000-50,000 Philippine pesos (USD 400$1,000)$ for each killing, "depending on the status" of the target. ${ }^{82}$ Two of his victims were his own drug-using brothers and a third was Jun Pala, whose critical radio commentaries angered Duterte.

Duterte has denied connections to Matobato and Lascanas and has refused responsibility for other extra-judicial killings in Davao. He also has denied claims of extra-judicial killing in his presidential war on drugs that were provided by 12 active and five former police officers in a 26-page report released to leaders of the Philippine Catholic Church and to the

\footnotetext{
76. Villamor (2017e).

77. Fenton, supra note 27.

78. Pamintuan, supra note 74.

79. Rauhala (2016).

80. BBC (2016).

81. Curato, supra note 62, p. 9.

82. Villamor (2017b).
} 
government-funded Commission on Human Rights in January $2017 .{ }^{83}$ But Duterte is hardly a model of consistency, and he also has claimed credit for both killing campaigns on numerous occasions. In 2009, for example, he said:

If you are doing an illegal activity in my city [Davao], if you are a criminal or part of a syndicate that preys on the innocent people of the city, for as long as I am the mayor, you are a legitimate target of assassination. ${ }^{84}$

And in a stump speech in front of 300,000 supporters in 2016, he said:

If I make it to the Presidential palace, I will do just what I did as mayor. All of you who are into drugs, you sons of bitches, I will really kill you. I have no patience, I have no middle ground, either you kill me or I will kill you idiots. ${ }^{85}$

Before Duterte became mayor of Davao, it was known as "Murder City." 86 Subsequently, many residents of Davao came to believe that governance Duterte-style brought safety and calm to a city that is "surrounded by areas where violence is rife." ${ }^{87}$ Nationally, "millions of Filipinos look at Davao's transformation with envy—whatever the cost." 88 They believe the Davao Death Squad helped deter crime and drug use, making the city one of the safest and most orderly in the Philippines. After 10 p.m., juveniles are not allowed on city streets unless an adult is accompanying them. Liquor cannot be sold after 1 a.m. Smoking is banned almost everywhere. Strict enforcement of low speed limits has reduced the number of motor vehicle accidents. Hundreds of closed-circuit TV cameras are constantly monitored at the city's Public Safety and Security Command Center. Public works projects are often done on time and within budget - a rare achievement in the Philippines. And so on. Inside the city and out, Davao is seen as an "enclave of peace and relative prosperity" and a "blueprint" for taming the rest of the country. ${ }^{89}$ It also has been named one of the Top 20 Most Liveable Cities in Asia. $^{90}$

But perception and reality can be two different things. We have found little solid evidence supporting the view that the Death Squad made Davao safer. In fact, according to police statistics, when Duterte became president in 2016, Davao had the highest murder rate and the second highest rape rate among 15 large Philippine cities. ${ }^{91}$ Nonetheless, many people regard the city as an oasis of safety surrounded by a sea of violence, and public belief in the efficacy of Duterte's policies in Davao—including governing through killing-helped propel him into the presidency. ${ }^{92}$ While campaigning for that office, Duterte promised that thousands of criminals and drug users would be killed under his leadership. By all appearances, he has been trying to make good on that promise. ${ }^{93}$

83. Special Report, supra note 28; Mogato \& Baldwin, supra note 63.

84. Ali \& Zanab (2017).

85. Campbell (2016).

86. Rauhala, supra note 79; see also Democracy Now (2016).

87. Whaley (2016).

88. Rauhala, supra note 79.

89. Whaley, supra note 87.

90. Curato, supra note 62.

91. Baldwin and Marshall (2016).

92. Paddock (2017).

93. Duterte is a man of multiple contradictions. He has been called a "mass murderer" (New York Times, supra note 32) but is also seen as a champion of the little guy. He is a promoter of women's rights who called his daughter a "drama 


\section{CAUSES}

Like many penal practices, extra-judicial killing in the Philippines is "overdetermined" in the sense that it is shaped by a wide range of forces. ${ }^{94}$ In this section, we take three passes at explaining this complex penal practice. First and most narrowly, we describe impunity in Philippine criminal justice in order to reveal some of the sources of public support for Duterte's extra-legal policies. Then we step back to consider the politics of penal populism in the Philippines. Duterte realized long ago that governing through killing appeals to large segments of the public and wins votes, regardless of its effectiveness at reducing crime or deterring drug use. Our final pass takes a broad view of democratic underdevelopment in the Philippines in order to suggest that Duterte's war on drugs is rooted in the economic and political failures that have plagued the country for decades. Since none of these causes is easy to change, extra-judicial killing could continue to occur long after Duterte leaves office.

\subsection{Criminal Injustice}

For decades before the slaughter that started in the summer of 2016, the Philippines had one of the highest rates of homicide in the world. ${ }^{95}$ In 2014, it had the highest homicide rate among 51 countries in "Asia." 96 With 9.8 homicides per 100,000 population, its homicide rate was twice as high as the rate for the US, three times higher than the average rate in Europe, and four times higher than the average rate for ten other countries in Southeast Asia. Because of underreporting and other data difficulties, it is hard to tell whether the Philippines has high rates for crimes such as theft, robbery, and rape but, in the years leading up to Duterte's election in 2016, official crime rates soared, at least partly because of increased reporting by police. ${ }^{97}$

The Philippines may also have higher rates of drug use and abuse than other countries in East and Southeast Asia, especially for methamphetamines (shabu). In 2014, 89\% of drug seizures in the country involved methamphetamines, $8.9 \%$ involved marijuana, and $2.1 \%$ involved other drugs. ${ }^{98}$ In 2011, the US State Department reported that $2.1 \%$ of Filipinos aged 16-64 abused methamphetamines. ${ }^{99}$ It is hard to tell because the data are of poor

\footnotetext{
(F'note continued) of critical essays on Duterte's early presidency, see Curato (2017a).

94. Garland (1990), p. 125.

95. Johnson \& Zimring, supra note 5, p. 109.

96. United Nations Office on Drugs and Crime (2014).

97. Ranada (2016).

98. Ibid.

99. United Nations World Drug Report (2012).
}

queen" after she said she was raped. During his presidential campaign, he told a packed stadium in Quezon City that, when he saw the corpse of Jacqueline Hamill, an Australian missionary who was gang-raped and murdered in Davao in 1989, "I got angry. That she was raped? Yes, that too. But it was that she was so beautiful-the mayor should have been first. What a waste." See Curato, supra note 62, p. 93. Space does not permit a detailed description of Duterte's life, but here are a few more salient facts. He was elected president at age 71, making him the oldest of the country's 16 presidents—and the first to come from the south. His father was a lawyer and governor of Davao province. His mother was a school teacher and political activist who frequently whipped her son. He was sexually abused by a Catholic priest when he was a boy. He was expelled from two high schools. He claims to have killed his first person at the age of 17 and thereafter he apparently shot a lawschool classmate for being a bully. He was a prosecutor for about ten years before becoming mayor of Davao for 22 years. After a motorcycle accident in 2013, he became addicted to the opioid fentanyl (a painkiller), which is far more potent than heroin and which, Duterte says, made him feel like he was on "cloud nine ... with nothing to worry about"; see ABS-CBN News (2017). For more details about Duterte's life, see Chen, supra note 34; Heydarian, supra note 64; and, for a collection 
quality, but there may be more than 1 million methamphetamine users in the country, ${ }^{100}$ and Duterte and others have claimed there are more than 3 million. ${ }^{101}$ Some methamphetamine users exhibit signs of addiction and acknowledge committing crimes in order to support their habit, but the best ethnographic work on this subject finds that most users remain functional and that the only crime many commit is taking drugs. ${ }^{102}$

But, for some Filipinos, methamphetamine is personally destructive and criminogenic. Trafficking is organized and financed mainly by ethnic Chinese gangs. Because the Philippines is located near large nations such as China, Indonesia, and Japan, it is a major hub for methamphetamines in the region. The Catholic Bishops Conference of the Philippines $2015^{103}$ released a pastoral letter calling methamphetamine the "poor man's cocaine" and warning that the drug is "dangerously ubiquitous" and "peddled openly in parks, bars, and street corners." Years earlier, Filipino bishops described drug users as "mental and physical wrecks" who were the "worst saboteurs" and who deserved "the highest punishments"views that are shared by many Filipinos. ${ }^{104}$ There are few rehabilitation facilities in the country, and treatment is all but impossible to obtain for the vast majority of drug users and addicts. ${ }^{105}$ To most Filipinos and many outside observers, the failure of Philippine drug policy is obvious. ${ }^{106}$

Although methamphetamine often harms individuals, families, and communities, it also performs positive functions, especially for the poor. ${ }^{107}$ It empowers manual labourers to work for long hours. It alleviates hunger. It provides emotional escape from the grinding conditions of daily life that millions of Filipinos endure. ${ }^{108}$ And, as Clarke Jones of Australian National University observes, "A lot of the people involved in the [methamphetamine] drug market have no other opportunity for income, so a lot of [the drug] money [they earn] also goes to support families in communities." ${ }^{109}$ In a country that has failed to address the circumstances that generate demand for methamphetamine, Duterte's war on drugs is considered a necessary evil by many Filipinos-including many who live in locations that are being targeted by this campaign. Unless the social and human sources of the country's drug problems are addressed, reduced drug use seems unlikely. ${ }^{110}$ The Philippines may well need a "war on drugs," but the war it has been fighting under Duterte seems to be the wrong war, fought with the wrong weapons, and against the wrong enemies. ${ }^{111}$ The root causes of the country's drug problem are poverty and corruption. ${ }^{112}$ If it does not reckon with the social and economic deficits that push people into drug use and trafficking, it will not be able to discourage demand for a substance that so many find appealing.

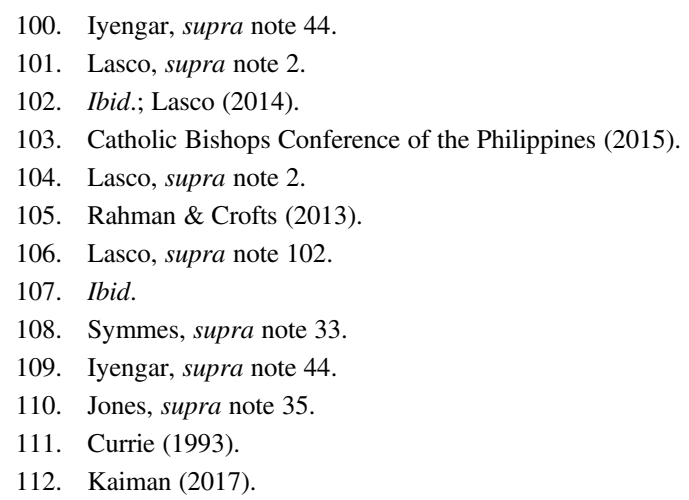


In addition to high rates of lethal violence, strong public demand for drugs, and deep public concern about drug-related problems, support for extra-judicial killing in the Philippines is fostered by the dysfunctions of its criminal justice system. ${ }^{113}$ Countries such as the US and Japan have serious criminal justice problems but, in many respects, they pale in comparison to those found in the Philippines. ${ }^{114}$ Most Filipinos believe there is little justice to be had from its "injustice system." 115 Its criminal process proceeds at a glacial pace. Its judiciary has a backlog of 600,000 cases and at least $20 \%$ of the country's trial courts lack judges. The average prosecutor handles 500 cases per year and the average public defender 5,000. The police are understaffed by about 50,000 officers and some analysts believe they are "the biggest criminal institution in the Philippines." ${ }^{116}$ Many persons accused of crime languish in jail for years, only to be released when police fail to testify or the evidence against them proves unreliable. Under Duterte's predecessor as president, Benigno Aquino III, only about $25 \%$ of criminal cases in the country ended in conviction - and that was an improvement over the previous administration of Gloria Macapagal Arroyo. During Duterte's war on drugs, Philippine courts—including the Supreme Court—have proved "incapable of asserting their independence and doing their work in a credible way," which motivated prosecutors in the International Criminal Court (ICC) to initiate their own investigations. ${ }^{117}$

In short, criminal justice in the Philippines is ineffective, inefficient, and corrupt. It is also toothless. ${ }^{118}$ According to Mexico's Center for Studies on Impunity and Justice, the Philippines has the highest Global Impunity Index of any country in the world-just above Mexico, where the drug trade and extra-judicial killing also flourish. ${ }^{119}$ These failures of criminal justice seem to be "at the root of broad acceptance of Duterte's draconian drug war." 120 They also help explain why millions of Filipinos cheer extra-judicial killing or passively acquiesce to it, even though there is little evidence that it actually deters drug use. ${ }^{121}$

\subsection{Penal Populism}

A sign in Davao reads: "Rody Duterte. The People's last hope.” It is a message that resonates in the city and throughout many of the 7,000 islands in the Philippine archipelago. The country cannot kill its way out of its drug and crime crisis, but Duterte and associates can exploit it for their own ends and in ways that serve the interests of many Filipinos. They have been doing just that in a display of penal populism that is both familiar and unique.

At its core, "penal populism" consists of the pursuit of punishment policies based primarily on their anticipated popularity rather than their effectiveness. ${ }^{122}$ Penal populism varies from place to place, but it also has qualities that are common in many countries,

113. Alston (2008); Alston (2009).

114. Narag (2005).

115. Syjuco, supra note 37.

116. Narag (2017b).

117. David (2018).

118. Syjuco, supra note 37.

119. Inzunza \& Veiras (2017).

120. Syjuco, supra note 37.

121. Rodis, supra note 51. In fact, as extra-judicial killings have increased in the Philippines, so, too, have the government's estimates of drug use; Tree (2018).

122. Pratt (2007), p. 2. 
including the Philippines. Penal populism tends to be strongest when it is directed at an unpopular enemy_- "others" who are defined as deviant and whose existence unites the public in indignation against them. In the Philippines, this group consists mainly of drug users and traffickers. Penal populism tends to be rooted in resentment against political elites and the existing political establishment. In the Philippines, there is little trust in the establishment to protect the interests or advance the wellbeing of ordinary people (two of the three presidents before Duterte were prosecuted for plunder). Penal populism tends to see the rights of offenders as favoured over those of victims and the law-abiding public. In the Philippines, criminal justice routinely fails to hold offenders accountable for their conduct. Penal populism turns the punishment of offenders into a spectacle for degrading them and for expressing the public's vengeful impulses. In the Philippines, extra-judicial killing is often staged in these ways. Penal populism informs and misinforms the public by relying on media representations that privilege "commonsensical" understandings of crime and punishment. In the Philippines, the media routinely reflect and reinforce the prevailing common sense. Penal populism implies little faith in government to solve crime problems, making vigilantism an appealing alternative response. In the Philippines, the war on drugs blurs the line between killing by government and killing by vigilantes. And penal populism undermines the rule of law and the independence of the judiciary, thereby strengthening the executive's hand. In the Philippines, these effects have been striking in Duterte's war on drugs. ${ }^{123}$

But if penal populism in the Philippines shares many qualities with penal populism in other countries, including its underlying causes, ${ }^{124}$ it is also distinctive, in four ways. First, Duterte's brand of penal populism is driven by both a politics of fear of crime and by a politics of hope that posits a better future once crime problems are under control. ${ }^{125}$ Central to both of these appeals is a posture that Duterte packs with "hyper masculinity." ${ }^{, 26} \mathrm{He}$ disdains formality, is given to profanity, is a confessed womanizer, and frequently "stands as the toughie ready to fight, kill, or die."127 All of these qualities make him seem "authentic," in contrast to the duplicity of the "decent" politicians who have traditionally ruled the country. ${ }^{128}$

Second, in countries such as Japan and the US, much populist anger is directed at immigrants who are said to pose a serious threat to the social order. In the Philippines, by contrast, immigration barely registers on the public radar. The presumed enemies of Philippine society are said to be internal: drug users and sellers, street criminals, and communist rebels. Emigration is a far more salient issue in the Philippines than immigration. Approximately 10 million people of Filipino descent work abroad and send back to their families tens of billions of dollars in remittances each year. ${ }^{129}$

123. Houle \& Kenny (2018).

124. In the Philippines and other societies, penal populism arises out of deep social changes that have been taking place since the 1970s, including: (1) a decline of deference to elites, which has weakened the authority of criminal justice officials; (2) a decline of trust in politicians and political processes, mainly because of the failure of politics-asusual to address the needs of ordinary people; (3) globalization, which has fuelled the perception that no one is in control of the country; and (4) heightened concerns about crime and insecurity and a perceived decline in social cohesion. Pratt (2007), pp. 36-65.

125. Curato (2016b).

126. Gutierrez (2017).

127. Ibid.

128. Heydarian, supra note 64.

129. Ibid. 
Table 3. Imprisonment rates and prison overcrowding in ten countries of Southeast Asia, 2017

\begin{tabular}{lcc}
\hline Country & Imprisonment rate & Occupancy level \\
\hline Thailand & 445 & $145 \%$ \\
Singapore & 222 & $79 \%$ \\
Malaysia & 167 & $114 \%$ \\
Cambodia & 159 & $206 \%$ \\
Philippines & 140 & $316 \%$ \\
Vietnam & 139 & $\mathrm{n} . \mathrm{a}$. \\
Brunei & 134 & $133 \%$ \\
Myanmar & 128 & $144 \%$ \\
Laos & 119 & $\mathrm{n} . \mathrm{a}$. \\
Indonesia & 86 & $183 \%$ \\
Average & 174 & $165 \%$ \\
\end{tabular}

Source: World Prison Brief (2017), hosted by the Institute for Criminal Policy Research at Birkbeck, University of London, www.prisonstudies.org.

Note: The imprisonment rate is the number of inmates in prison and jail per 100,000 population. The occupancy level is the total number of inmates in prison and jail divided by the official capacity of the prison and jail system. No figures are available for Timor-Leste.

Third, in most countries, the central tool of penal populism is imprisonment ${ }^{130}$ but, in the Philippines under Duterte, extra-judicial killing has become its most salient feature. The Philippine imprisonment rate did increase in recent years, from 83 inmates per 100,000 population in 2002 to 140 in 2016. But almost all of this rise occurred before Duterte's war on drugs started and, even after the rise, the country's imprisonment rate remained lower than the average imprisonment rate (174) of the countries in Southeast Asia for which evidence is available, and it was less than one-third the imprisonment rate of Thailand (445), the leading incarcerator in the region. ${ }^{131}$ At present, imprisonment in the Philippines is distinctive mainly because its seven national prisons and 1,130 local jails are operating at more than $300 \%$ of official capacity, making its correctional system far and away the most crowded one in the region. Prison and jail conditions in the country are brutal ${ }^{132}$ but, in comparative perspective, what stand out in the Philippine form of penal populism are the frequency of its extra-judicial killing and the open acknowledgement of state acts that are clearly illegal (see Table 3). ${ }^{133}$

The fourth Philippine distinctive is the connection between penal populism in the present and the long tradition of extra-judicial killing in the "local bossism" of the past. ${ }^{134}$ Traditionally, who was targeted for extra-judicial killing (and for what activities) was largely

130. Roberts et al. (2003), p. 50.

131. World Prison Brief (2017).

132. Narag, supra note 114.

133. Compared to some other countries in Southeast Asia, these are differences of degree, not kind. For example, Thailand's prime minister, Thaksin Shinawatra, initiated a war on drugs in 2003 that killed 2,800 people in its first three months, more than half of whom had no connection to illicit drugs; see Human Rights Watch (2017). And, in 2017, Indonesian President Joko Widodo instructed police to shoot drug traffickers "because we are indeed in a narcotics emergency position now." See Bangkok Post (2017).

134. Berlow (1996). 
determined by dynastic political bosses who ruled like feudal lords in "an anarchy of families." ${ }^{135}$ Local bosses and their extended families dominated their domains by engaging in predatory, kleptocratic, rent-seeking behaviour, and by committing murders with impunity. ${ }^{136}$ Local bosses also resembled gang leaders in several ways. They engaged directly in crime. They provided protection for associates who were involved in criminal activities (including the drug trade). They practised passive non-interference in illegal activities - a form of tacit support that protected them from legal culpability. And they allowed the criminal and entrepreneurial activities of local police to go unchecked (blackmails, kidnaps, corruption, and so on). When Duterte was mayor of Davao, he played all of these local boss roles and, even after he left the second most populous city in the country to be governed by his daughter Sara and son Paolo (mayor and vice-mayor, respectively), Davao is still known as "Duterte city."137

Although the war on drugs in the Philippines seems singular in some ways, its commonalities with drug wars in other countries are especially significant. Indeed, in directing his war on drugs, Duterte-a former prosecutor-is "governing through crime" much as his American counterparts have done, albeit with far more lethality. ${ }^{138}$ Three similarities are striking. First, when Duterte orders and condones extra-judicial killing, he is seen as acting legitimately because he claims to be trying to prevent crime and other bothersome behaviour. This is one hallmark of "governing through crime."139 Second, Duterte frequently deploys the problems of "crime" and "drug abuse" to legitimate governmental interventions (such as the arrest and killing of critics and rivals) that have other motivations. This, too, has been common in American efforts to govern through crime. ${ }^{140}$ Most fundamentally, Duterte's government fosters fear in Filipinos-fear of crime, fear of drugs, and fear of official responses to both-because he realizes that this emotion is an effective instrument of governance. In America, too, the lives of many citizens have been transformed not so much by crime per se as by fear of crime. ${ }^{141}$ In short, the war on drugs in the Philippines may seem uniquely horrifying in its bloodiness and brutality but, in many of its essentials, it is surprisingly familiar.

\subsection{Democratic Underdevelopment}

The scale of extra-judicial killing in Duterte's war on drugs reflects fundamental economic and political failures in Philippine society. The country is not a "failed state" like North Korea, Sierra Leone, or Zimbabwe, but it is dysfunctional in significant ways. In 2017, its GDP per capita (Purchasing Power Parity) of USD 7,700 placed Asia's oldest democracy 154th out of the 230 countries in the CIA World Factbook - a little below Jamaica and Guatemala, and a little above India and the Republic of the Congothat also have had problems with extra-judicial executions. According to Freedom House, ${ }^{142}$

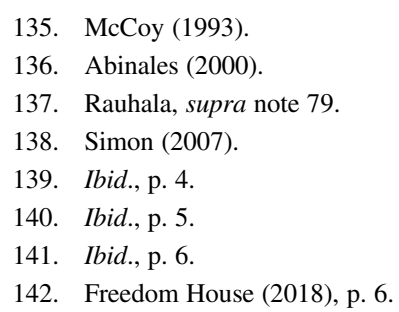


the Philippines earns a score of only 4 out of 16 for the "Rule of Law" because the application of law and justice in the country are "haphazard" and "heavily favor ruling dynastic elites."

In addition to the problems of economic and legal underdevelopment, there are also the legacies of colonialism. The Philippines is "America's only major colonial experience"143 and, before the half-century of repressive American rule (1898-1946), there was exploitation by the Spanish for nearly four centuries (1521-1898) and a brutal occupation by the Japanese during the Pacific War (1942-45). Few countries are more "shackled by the past." ${ }^{144}$ After one of the longest continuous periods of colonial rule in world history, the Philippines is now doubly dependent: on a colonial mentality produced by its experiences with America, Spain, and Japan; and on its own entrenched oligarchy.

The extent of dynastic rule in the Philippines is stunning, exceeding even those that are found in the countries of Latin America. ${ }^{145}$ The Dutertes-father Rodrigo and eldest daughter Sarahave held the mayorship of Davao for the last 30 years and the dynastic share of governors in the rest of the country exceeds $80 \%$. The dynastic shares for other elected positions are also high: $81 \%$ for vice-governors, $77 \%$ for the House of Representatives, $69 \%$ for mayors, and $57 \%$ for vice-mayors. ${ }^{146}$ In many parts of the Philippines, only the rich and those with the correct last name enjoy the entitlement of leadership, and leaders routinely exercise their powers to feather their own nests rather than to promote the common good. As Alan Berlow observed in his trenchant analysis of murder and revenge on the island of Negros, the Philippines is a society

with no functioning system of law or justice, where government was either absent or irrelevant, and the rules regulating everyday life were dictated by a revolving cast of vigilantes, fanatical cultists, Communist revolutionaries, private armies, and the military. The Philippines may have proclaimed itself a democracy, but in Negros [and other parts of the country] almost everyone vying for power was equally committed to the subversion of democratic institutions. ${ }^{147}$

Ultimately, the post-colonial Republic of the Philippines remains poor because it continues to be ruled by a narrow elite that organizes society for its own benefit, at the expense of the vast majority of its citizens. Part of this problem is corruption, which is so extensive that many leaders and local governments resemble glorified gangs. ${ }^{148}$ In the Philippines, as in some other societies, "thieves of state" present grave threats to both development and security. ${ }^{149}$ But the root of the country's most serious problems is political. Economic institutions are critical for determining whether a country becomes poor or prosperous, but it is politics and political institutions that determine what economic institutions and incentives

\footnotetext{
143. Karnow (1989), p. xi.

144. Ibid., p. 25.

145. Heydarian, supra note 64. In most democracies, the proportion of elected offices controlled by dynastic families rarely exceeds $10 \%$; Smith (2018).

146. Abinales \& Amoroso, supra note 21, p. 339.

147. Berlow, supra note 134, p. xiv.

148. President Duterte is often praised for living a life of apparent simplicity, but the Philippine Office of the Ombudsman is investigating complaints that he amassed 2.2 billion pesos (USD 43 million) in wealth while he was mayor of Davao and his son Paolo (the vice-mayor of Davao) was investigated by the Senate for allegedly helping to import USD 125 million worth of narcotics from China. See Reuters Staff (2017); Lema (2017). It is impossible for us to discern whether these allegations have merit, but there is no doubt about the more general matter: the Philippines is corrupt. In Transparency International's Corruption Perception Index for 2016, the country received the same ranking as Thailand and Timor-Leste (101 out of 176 countries) and was deemed more corrupt than Brazil, China, India, and Indonesia; see Transparency International (2016).
}

149. Chayes (2015). 
a country has. ${ }^{150}$ Similarly, if one central conservative truth is that culture largely determines the success of a society, "the central liberal truth is that politics can change a culture and save it from itself." ${ }^{\prime 51}$ Politics also underlies the problem of extra-judicial killing in the Philippines. It is no coincidence that politics and state institutions are central in explanations for the trajectory of that other type of state killing known as "capital punishment."152

\section{KILLING AND REFORM?}

On 24 July 2017, in his second state of the nation address, President Duterte stressed that his war on drugs would be "unremitting" and "unrelenting":

[P]rogress and development will sputter if criminals, illegal drugs, and illegal users of drugs are allowed to roam the streets freely, victimizing seemingly with impunity, the innocent and the helpless ... I have learned that the economy surges only when there is peace and order prevailing in places where investors can pour in their capital and expertise. I have learned from my experience in Davao City that investor confidence is bolstered and fortified, only if, a potent force and mechanism for the protection of local and foreign investments are in place. That is why I have resolved that no matter how long it takes, the fight against illegal drugs will continue, because that is the root cause of so much evil and so much suffering that weakens the social fabric and deters foreign investments from pouring in. The fight will be as unremitting as it will be unrelenting. Despite international and local pressures, the fight will not stop until those who deal in it understand that they have to cease, they have to stop, because the alternatives are either jail or hell .... Neither will I be immobilized into inaction by the fear that I will commit an act that will expose me to public condemnation or legal prosecution. You harm the children in whose hands the future of this Republic is entrusted, and I will hound you to the very gates of hell ... Do not try to scare me with prison or the International Court of Justice. I am willing to go to prison for the rest of my life. ${ }^{153}$

Three weeks after this speech, Duterte's war on drugs produced what may have been its "bloodiest days on record." ${ }^{154}$ In the province of Bulacan, seven miles north of Manila, 32 "drug suspects" were killed and 109 were arrested over a 24-hour period on 14 and 15 August. The next day in Manila, 26 people were killed in a crackdown that police called a "one-time, big-time" operation against illegal drugs, and Duterte declared that police should shoot human rights activists if they try to obstruct justice. National police chief Ronald dela Rosa said there would be no let-up in the war on drugs. "This is unrelenting," he stated. "We will continue to operate until the end." 155

150. Acemoglu \& Robinson (2012).

151. Huntington (2000), p. xiv.

152. Zimring, supra note 68, p. 22; Johnson \& Zimring, supra note 5, p. 295; Garland (2010), p. 127.

153. In this speech, Duterte (2017) also discussed a bloody two-month uprising by pro-Islamic State militants in the southern city of Marawi that led to the deaths of 421 militants, 99 soldiers, and 45 civilians-a much smaller death toll than that caused by the crackdown on drugs in the first two months of his presidency. At the time of this speech, the Philippine Congress, which was dominated by Duterte's supporters, had just granted his request to extend martial law in the southern part of the country through the end of 2017, which Duterte claimed would help restore "public safety and law and order in the whole of Mindanao"; see Villamor (2017f). Critics said martial law powers were unnecessary to defeat the fewer than 100 militants who remained in Marawi, and they worried that Duterte was using the crisis as an excuse to impose authoritarian rule throughout the country. In a news conference after this speech, Duterte threatened to order airstrikes against tribal schools he accused of teaching students to become communists; see Honolulu Star-Advertiser (2017).

154. Asian Correspondent Staff (2017).

155. Ibid. 
We do not expect extra-judicial killing in the Philippines to end anytime soon, for it has been a prominent feature of the country's political landscape for decades, and it has been a major source of Duterte's popularity. But in the second year of Duterte's presidency, there was a significant pause in governing through killing. The precipitating circumstance was the extrajudicial execution of 17-year-old Kian Loyd delos Santos in the 16 August crackdown in Caloocan City in metro Manila. Delos Santos had never been in trouble with the law and was not on any police watch list. According to family and friends, he wanted to become a police officer, he did not use or sell drugs, and he supported the war on drugs. After his execution, the police claimed that he had fled when they approached him and then had shot at them during the ensuing chase. The right-handed delos Santos was found dead in an alley with a 45-calibre pistol in his left hand and two sachets of methamphetamine on his person. He had three gunshot wounds: one in the back of his head, another behind his left ear, and a third inside his left ear. The usual police story- "we fired because we were fired upon"- - might have prevailed if not for a CCTV video taken in the ward where delos Santos lived. It showed him being dragged away by two men in plainclothes at 8:24 p.m., just minutes before he was found dead. Several residents of the ward also came forward with eyewitness accounts that contradicted the police version of events. These revelations received intense coverage in the Philippine media (including Facebook and Twitter) and many public protests occurred in the weeks that followed, led by the Catholic Church and by activists who denounced Duterte's drug crackdown. ${ }^{156}$ Several senators publicly condemned the killing of delos Santos and the war on drugs, as did prominent Catholic priests. Opinion polls showed rising levels of public concern about police conduct in the war on drugs and falling levels of public support for Duterte. In October, domestic and international criticism prompted Duterte to announce that he was ending the war or drugs. ${ }^{157}$ For the rest of 2017, while Duterte's popularity rebounded, there was little clear evidence of extra-judicial killing, though the president did occasionally proclaim that his war on drugs would continue. In a speech on 8 December, he said:

I don't care if you call me killer .... Who would not be a killer? So is it wrong to say now, "Do not destroy my country because I will destroy you?" .... There will be no drugs. I don't care if I lose my job, the presidency, or if I get killed. I promised the Filipino people during the campaign and I will do it whether you like it or not. Sorry but I don't care about your opinion about me. ${ }^{158}$

On 29 January 2018, Philippine National Police Director General Ronald dela Rosa announced that the war on drugs would resume with a new and improved Operation Knock-and-Plead. He expressed hope that police operations would be less violent this time, but he stressed that he could not guarantee that the renewed campaign would be bloodless. The behaviour of police would depend on the reactions of the people they targeted. "Don't fight back," he said. "[We] have to preserve our own lives."159

156. Villamor (2017c).

157. On 31 August 2017, the National Bureau of Investigation filed a complaint against four Caloocan City police for the murder of delos Santos and the planting of evidence; see Buan (2017). Five months later, the Department of Justice indicted three of those officers (plus one civilian) for those crimes and for raiding delos Santos's home without a search warrant, but the complaint against their station commander was dropped for lack of evidence; see Buan (2018). For a case in which a drug-raid survivor took the police to court, see Villamor (2017a).

158. Gita (2017).

159. Cabico (2018). 
Dela Rosa also emphasized that the new and improved war on drugs would respect human rights and be governed by the rule of law. He even released an instruction manual with guidelines describing how drug operations should proceed. Among other promised reforms, the drug watch list (the "Bible" of Knock-and-Plead) should be kept accurate and updated, police who participate in drug crackdowns should receive one day of training, anti-drug operations should be carried out only between 8:00 a.m. and 5:00 p.m. Mondays to Fridays, police should remember to wear their uniforms during these operations, and there should be "command responsibility" for the failures of subordinates that can be traced to the negligence or misconduct of police leaders. ${ }^{160}$ Dela Rosa even invited the public to come along on the new Knock-and-Plead operations, saying that "anybody who wants to join" is welcome to do so because police "aren't hiding anything." ${ }^{161}$ In support of this new approach to the war on drugs, presidential spokesperson Harry Roque said: "We are hoping it will be [less bloody] and we welcome the statement by the PNP as reaffirming [the police] commitment to the rule of law." 162

Controversy about the war on drugs is undesirable, Roque observed, because it blurs the government's real intention, which is "the fight against dangerous drugs." ${ }^{163}$ Romulo Valles, the Archbishop of Davao and the new president of the Catholic Bishops' Conference of the Philippines - as well as a close friend of Duterte—stressed that police should "follow the prescribed steps" in the new guidelines so that "as much as possible we must make sure that we do not waste any lives." 164

\section{LESSONS}

Time will tell how much extra-judicial killing occurs in the Philippines under new guidelines that purportedly leave "no space for possible abuse."165 Time will tell, too, whether capital punishment will be reinstated in the Philippines once again, as Duterte is trying to do. In his second state of the nation address, he stressed that death-penalty revival was his top legislative priority ${ }^{166}$ and he said he wants five or six legal executions carried out every day, by hanging. ${ }^{167}$ Unless Duterte dies, is removed from office, or is able to change the term limit rule for presidents, his one and only presidential term will end in June 2022. There is also the ICC in The Hague, which, in February 2018, opened an investigation into accusations

160. The new guidelines for Knock-and-Plead are organized in seven steps, as follows: (1) the creation and updating of the drug watch list; (2) the creation and training of police teams; (3) pre-deployment preparations; (4) knock then plead; (5) documentation and referral; (6) the submission of "after activity reports" to regional police authorities, the sharing of "best practices," and performance evaluations; and (7) increased accountability for front-line police and their superiors; Talabong (2018a).

161. Talabong (2018b).

162. Ranada (2018b).

163. Roque has impressive human rights credentials. He is a lawyer and former law professor who taught constitutional law and international law at the University of the Philippines for 15 years and who worked on cases involving human rights violations in the Maguindanao massacre of 2009. He has stood up to Duterte on some matters of principle (e.g. "I'll resign if Duterte tramples press freedom"), but in his role as presidential spokesperson he has also made compromises with human rights and defended Duterte's attack on Rappler, the domestic media organization that has provided the most comprehensive coverage of the war on drugs; Ranada (2018a); Ranada (2018b).

164. Cabrera (2018).

165. Talabong, supra note 160.

166. Mendez \& Regalado (2017).

167. The Nation \& AFP (2016). 
that Duterte and other Philippine officials had committed crimes against humanity during the government's deadly crackdown on drugs. ${ }^{168}$ This chapter in the history of state killing in the Philippines is far from finished, but we can identify five lessons from it that students of law and society should learn.

First, extra-judicial killing deserves more study than it has so far received. Compared with the number of studies of judicial killing through institutions of capital punishment, studies of extrajudicial killing are few and far between, especially in the field of punishment and society. In some ways, this imbalance resembles the extreme imbalance between the salience of capital punishment (high) and the salience of killings by police (low) in academic and media works about the US. ${ }^{169}$ Historians, area studies scholars, and NGOs have frequently described extrajudicial killing, but their works have rarely informed thinking about extra-judicial killing as a form of social control or a type of punishment. The best sociological accounts of genocide and governmental violations of human rights tend to focus on judicial responses to such offences, not on the offences themselves. ${ }^{170}$ If law is usefully conceived as "governmental social control," as one classic account argues, ${ }^{171}$ then the failure to connect with works in other fields is unfortunate for the study of law and society. Similarly, if studies of penality should be broad, both substantively and comparatively, ${ }^{172}$ then the failure to connect with works in other fields is unfortunate for students of punishment and society too. The study of extra-judicial killing does face empirical and conceptual challenges. ${ }^{173}$ For one thing, governments that kill extra-legally are seldom as brazen about it as Duterte has been. ${ }^{174}$ For another, there are different types of "extra-judicial killing" that use of one broad label obscures. ${ }^{175}$ We leave these and other challenges for future researchers to address. The subject is so interesting, important, and neglected that we hope the challenges will do more to spur further study than to discourage it.

Second, students of capital punishment should be less sanguine about the consequences of abolition. The authors of this article oppose capital punishment and want to see it abolished everywhere, but we are also realists about the effects of abolition. The record suggests that state killing does not necessarily decline after the death penalty is abolished-as the Philippines illustrates. One analysis of the second abolition of capital punishment in the Philippines was entitled “A Lesson Learned?". 176 The authors' answer to the titular question was "probably" and their prediction was that the Philippines would not attempt to reinstate capital punishment again. They were wrong. Their 43-page chapter also had little to say about extra-judicial killing. A similar form of death-penalty myopia can be seen in studies of

\footnotetext{
168. Villamor (2018b). In March 2018, Duterte declared that the Philippines would withdraw from the treaty that established the ICC because the ICC was "being utilized as a political tool" against his country; Villamor (2018a). Some scholars believe the war on drugs in the Philippines constitutes "an act of genocide" because it satisfies the eight stages of genocide described by Gregory. The stages are: classification, symbolization, dehumanization, organization, polarization, preparation, extermination, and denial; see Stanton (2018); Simangan (2017).

169. Zimring, supra note 28, pp. 6-12.

170. For a foundational work of world history that could be used to further develop the study of extra-judicial killing, see Kiernan (2007), on righteous, religious, and racial genocides, and exterminations from Sparta to Darfur; see also Hagan (2003); Savelsberg (2015).

171. Black (1976), p. 2.

172. Garland (1999).

173. Belur, supra note 26.

174. Campbell \& Brenner (2002).

175. Kaufman \& Fagan, supra note 14.

176. Johnson \& Zimring, supra note 5, Chapter 4.
} 
India, ${ }^{177}$ Indonesia, ${ }^{178}$ China, ${ }^{179}$ countries with majority Muslim populations, ${ }^{180}$ and countries in Africa ${ }^{181}$ _ just to name a few. More generally, the persistence of extra-judicial killing after death penalties are abolished or moratoria on judicial executions are declared suggests that there is reason to wonder whether "violence" has really declined as broadly and deeply as some scholars have argued. ${ }^{182}$

Third, penal populism and governing through crime are common not only in developed societies, but also in those that are developing. Most studies that have employed these perspectives have focused on developed democracies in the West, and they have greatly improved our understanding of the politics of punishment. ${ }^{183}$ But there are many less developed societies where penal populism is practised, and there are many more where leaders have realized that governing through crime brings large benefits. ${ }^{184}$ In our view, students of punishment and society have much to learn about the politics of punishment in societies that are not WEIRD—not Western, educated, industrialized, rational, and democratic - much as students of moral psychology have gained new insights by analyzing the attitudes of people who are not WEIRD in these five ways. ${ }^{185}$ Extending studies of penal populism to non-WEIRD societies will produce knowledge about how it differs from context to context, such as the finding that extra-judicial killing is a far more prominent feature of penal populism in the Philippines and Thailand than it is in (say) the US and Japan. At the same time, studies of non-WEIRD societies may replicate findings from the research on penal policy in modern and post-modern societies, such as the discovery that, in some Western societies, public concern about crime and media coverage of crime are closely connected to actual crime trends. ${ }^{186}$

Fourth, scholars have long recognized that there are tensions and tradeoffs between crimecontrol values and due-process values, ${ }^{187}$ but less appreciated is the fact that failures of crime control can motivate disregard for due process. The problem of impunity in Philippine criminal justice - the failure to catch and convict criminals - is so severe that many Filipinos believe ignoring rights is both justified and imperative. ${ }^{188}$ This is the fertile ground of public opinion in which Duterte's brand of penal populism finds root, and it can be found in other societies where extra-judicial killing is common, from India and Indonesia to Mexico and Honduras. Law and society is a large tent in which a wide variety of good research gets done but, in our view, the field would be enriched if more scholars took seriously the crime-control failures that help explain why violence is "far more serious, pervasive, and devastating in some places than others." 189

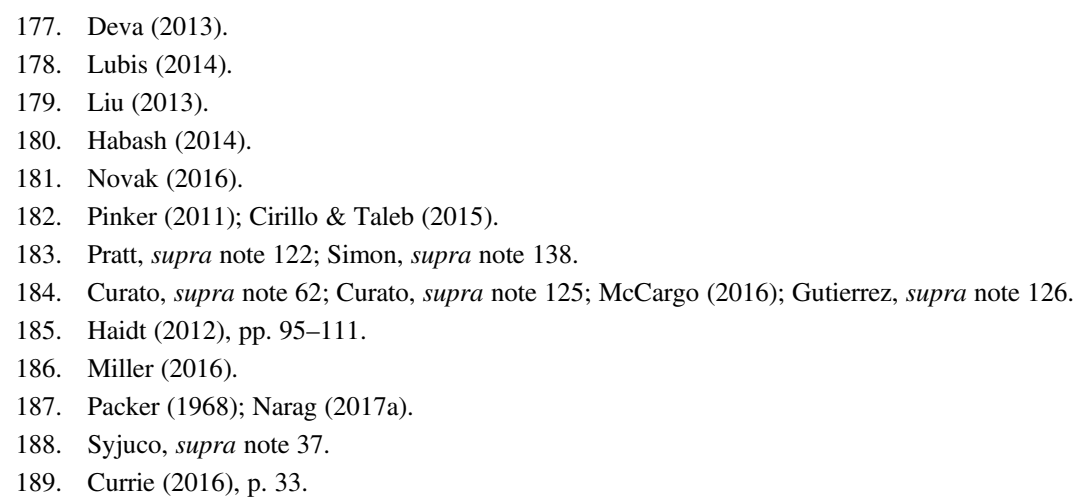


Finally, the number of democracies in the world increased markedly after World War II, from 30 or so to more than 100 . Since 2000, however, nation-states of major significance, including Russia, Turkey, Thailand, and the Philippines, have gone in the opposite, authoritarian direction. ${ }^{190}$ More broadly, many analysts believe that liberal democracy is "retreating" in the West and elsewhere ${ }^{191}$ and that authoritarianism is "going global."192 As democracy declines, so, too, might resistance to state killing, both judicial and extra-judicial. In the twentieth century, the "character of government" shaped death-penalty policy in three ways, especially in Europe. Fascist and totalitarian governments such as Germany, Italy, and the Soviet Union had obvious affection for high rates of execution. Europe's remarkably rapid movement toward abolition occurred mainly during two political transitions: one following the defeat of the Axis powers in 1945 and the other following the fall of the Soviet Union in 1989. And shifts of government from right-of-centre to left-of-centre precipitated death-penalty decline in countries such as England, France, and Spain. We do not know whether the current "democratic recession" will turn into a "global depression" 193 but, if it does, there could be surges in state killing in various countries. In this context, the case of the Philippines illustrates two political truths of broad relevance: that it is difficult to make a real democratic revolution succeed and that nations do not shed their pasts like snakes their skins. ${ }^{194}$ The Philippines is the only Christian nation in Asia - and the most Westernized one as well. Yet, in many ways, it remains a feudal society dominated by a small oligarchy. ${ }^{195}$ Unless the country undergoes deeper democratic development than it has experienced since Marcos was overthrown three decades ago, eruptions of extra-judicial killing will probably continue to occur, and another revival of capital punishment could occur as well. In the rest of the world, the erosion of democracy may augur ill for people who believe states should not kill their own citizens.

\section{REFERENCES}

Abinales, Patricio N. (2000) Making Mindanao: Cotabato and Davao in the Formation of the Philippine Nation State, Manila: Ateneo de Manila University Press.

Abinales, Patricio N., \& Donna J. Amoroso (2017) State and Society in the Philippines, 2nd edn, Lanham, MD: Rowman \& Littlefield Publishers.

ABS-CBN News (2017) "Duterte on Fentanyl Use: Felt Like Cloud Nine," 10 February, http://news. abs-cbn.com/news/02/10/17/duterte-on-fentanyl-use-felt-like-cloud-nine (accessed 26 February 2018).

Acemoglu, Daron, \& James A. Robinson (2012) Why Nations Fail: The Origins of Power, Prosperity and Poverty, New York: Crown Publishing Group.

Ali, Jibril, \& T. S. Zanab (2017) "Death Squads in the Philippines: Duterte's War on Drugs," Outsider, 7 June.

Alston, Philipp (2008) "Mission to Philippines: Report of the Special Rapporteur on Extrajudicial, Summary or Arbitrary Executions," http://www.karapatan.org/files/English_Alston_Report_Mission_ to_the_Philippines_HRC8.pdf (accessed 26 February 2018).

190. Remnick (2017).

191. Luce (2017); Diamond \& Plattner (2015).

192. Diamond et al. (2016); Levitsky \& Ziblatt (2018).

193. Luce, supra note 191.

194. Berlow, supra note 134.

195. Abinales \& Amoroso, supra note 21. 
Alston, Philipp (2009) "Report of the Special Rapporteur on Extrajudicial, Summary or Arbitrary Executions: Follow-Up to Country Recommendations-Philippines," https://reliefweb.int/ sites/reliefweb.int/files/resources/B677F4FDAA1A0443492575CA0023F346-Full_Report.pdf (accessed 26 February 2018).

Amnesty International (2017) "Philippines: 'If You Are Poor You Are Killed': Extrajudicial Killings in the Philippines' 'War on Drugs'." ASA 35/5517/2017, 31 January, 1-68.

Arceo, Acor (2016) “Aquino's Human Rights Record a 'Failure'-Watchdog,” http://www.rappler. com/nation/120590-human-rights-watch-aquino-failure (accessed 27 February 2018).

Asian Correspondence Staff (2017) “'Let's Kill Another 32 Every Day': Philippines Drug War Sees Deadliest Days on Record," https://asiancorrespondent.com/2017/08/lets-kill-another-32-everyday-philippines-drug-war-sees-deadliest-days-record/\#VjcHwWUQAUo6SvZ3.97 (accessed 26 February 2018).

Baldwin, Clare (2016) "Police Rack Up Almost Perfectly Deadly Record in Philippine Drug War," https:// www.reuters.com/investigates/special-report/philippines-duterte-police/ (accessed 26 February 2018).

Baldwin, Clare, \& Andrew R. C. Marshall (2016) "Suspect Stats: As Death Toll Rises, Duterte Deploys Dubious Data in 'War on Drugs'," Reuters, 18 October, https://www.reuters.com/investigates/ special-report/philippines-duterte-data/ (accessed 27 March 2018).

Bangkok Post (2017) "Jokowi’ Backs Shooting Drug Dealers," Bangkok Post, 22 July.

Barrera, Dan Jerome (2017) "Drug War Stories and the Philippine President." 12 Asian Journal of Criminology 341-359.

BBC (2016) "Philippines: Duterte Confirms He Personally Killed Three Men," 16 December, http://www.bbc.com/news/world-asia-38337746 (accessed 26 February 2018).

Belur, Jyoti (2010) Permission to Shoot: Police Use of Deadly Force in Democracies, New York: Springer.

Berlow, Alan (1996) Dead Season: A Story of Murder and Revenge, New York: Vintage.

Black, Donald (1976) The Behavior of Law, New York: Academic Press.

Black, Donald (1983) "Crime as Social Control." 48 American Sociological Review 34-45.

Brown, Michelle (2009) The Culture of Punishment: Prison, Society, and Spectacle, New York: New York University Press.

Buan, Lian (2017) "NBI: Cops Murdered Kian delos Santos, Planted Evidence," https://www.rappler. com/nation/180781-nbi-complaint-kian-delos-santos-murder-planting-evidence (accessed 26 February 2018).

Buan, Lian (2018) "DOJ Orders Filing of Murder Charges vs Cops in Kian Slay," https://www.rappler. com/nation/194749-doj-murder-charges-cops-kian-delos-santos-slay (accessed 26 February 2018).

Bueza, Michael (2017) "In Numbers: The Philippines' 'War on Drugs'," http://www.rappler.com/ newsbreak/iq/145814-numbers-statistics-philippines-war-drugs (accessed 26 February 2018).

Cabico, Gaea Katreena (2018) "Bato: I Can't Give You 100\% Bloodless Anti-Drug Operations," The Philippine Star, 29 January.

Cabrera, Romina (2018) "Tokhang Relaunched Today," The Philippine Star, 29 January.

Campbell, Bruce B., \& Arthur D. Brenner, eds. (2002) Death Squads in Global Perspective: Murder with Deniability, London: Palgrave Macmillan.

Campbell, Charlie (2016) "Why the Philippines Elected 'the Punisher' as President," Time, 23 May.

Catholic Bishops Conference of the Philippines (2015) "Addiction, Freedom and Disciples, CBCP Pastoral Letter on Drug Trafficking and Drug Addiction," http://cbcpwebsite.com/Messages/ addiction.html (accessed 26 February 2018).

Chayes, Sarah (2015) Thieves of State: Why Corruption Threatens Global Security, New York: W. W. Norton \& Company.

Chen, Adrian (2016) "The Tough Guy: When a Populist Demagogue Takes Power," The New Yorker, 21 November.

Cirillo, Pasquale, \& Nassim Nicholas Taleb (2015) "On the Tail Risk of Violent Conflict and Its Underestimation." Research Paper, New York University, School of Engineering.

Cupin, Bea (2017) “'Satisfaction' with War on Drugs Drops-SWS Survey,” https://www.rappler. com/nation/167269-sws-survey-war-on-drugs-march-2017 (accessed 27 February 2018). 
Curato, Nicole (2016a) "Flirting with Authoritarian Fantasies? Rodrigo Duterte and the New Terms of Philippine Populism." 47 Journal of Contemporary Asia 142-153.

Curato, Nicole (2016b) "Politics of Anxiety, Politics of Hope: Penal Populism and Duterte's Rise to Power." 35 Journal of Current Southeast Asian Affairs 91-109.

Curato, Nicole (2017a) A Duterte Reader: Critical Essays on Rodrigo Duterte's Early Presidency, Ithaca, New York: SEAP Publications of Cornell University Press.

Curato, Nicole (2017b) "In the Philippines, All the President's People," https://www.nytimes.com/ 2017/05/31/opinion/philippines-rodrigo-duterte.html (accessed 26 February 2018)

Currie, Elliot (1993) Reckoning: Drugs, the Cities, and the American Future, New York: Hill and Wang.

Currie, Elliot (2016) The Roots of Danger: Violent Crime in Global Perspective, New York: Oxford University Press.

David, Randy (2018) “A Nation's Obligation to Humanity," Philippine Daily Inquirer, 14 January.

de Guzman, Chad (2017) "PCO to Launch President's National TV Show," http://cnnphilippines.com/ news/2017/05/17/PCO-duterte-TV-show.html (accessed 26 February 2018).

Demick, Barbara (2016) "Rodrigo Duterte's Campaign of Terror in the Philippines," https://www. newyorker.com/news/news-desk/rodrigo-dutertes-campaign-of-terror-in-the-philippines (accessed 26 February 2018).

Democracy Now (2016) "Hit Man Recalls Violent Past of Philippine President as Wave of Killings Raises Human Rights Concerns," https://www.democracynow.org/2016/9/16/hit_man_recalls_violent_ past_of (accessed 26 February 2018).

Deva, Surya (2013) "Death Penalty in the 'Rarest of Rare' Cases: A Critique of Judicial Choice Making," in R. Hood \& S. Deva, eds., Confronting Capital Punishment in Asia: Human Rights, Politics and Public Opinion, Oxford: Oxford University Press, 238-286.

Diamond, Larry, \& Marc F. Plattner (2015) Democracy in Decline?, Baltimore: Johns Hopkins University Press.

Diamond, Larry, F. Plattner Marc, \& Christopher Walker (2016) Authoritarianism Goes Global: The Challenge to Democracy, Baltimore: Johns Hopkins University Press.

Drumbl, Mark A. (2000) "Sclerosis: Retributive Justice and the Rwandan Genocide." 2 Punishment and Society 287-307.

Fenton, James (2017a) "Duterte's Last Hurrah: On the Road to Martial Law," http://www.nybooks. com/articles/2017/02/23/duterte-philippines-road-to-martial-law/ (accessed 26 February 2018).

Fenton, James (2017b) "Murderous Manila: On the Night Shift," http://www.nybooks.com/articles/ 2017/02/09/murderous-manila-on-the-night-shift/ (accessed 26 February 2018).

Freedom House (2018) https://freedomhouse.org/country/philippines (accessed 27 February 2018).

Garland, David (1990) Punishment and Modern Society: A Study in Social Theory, Chicago: University of Chicago Press.

Garland, David (1999) "Editorial: Punishment and Society Today." 1 Punishment \& Society 5-10.

Garland, David (2005) "Penal Excess and Surplus Meaning: Public Torture Lynchings in TwentiethCentury America." 39 Law \& Society Review 793-834.

Garland, David (2010) Peculiar Institution: America's Death Penalty in an Age of Abolition, Cambridge, MA: Harvard University Press.

Garland, David (2018) "Theoretical Advances and Problems in the Sociology of Punishment." 20 Punishment \& Society 8-33.

Gayle, Damian. (2016) "Barack Obama Cancels Meeting after Philippines President Calls Him 'Son of a Whore', https://www.theguardian.com/world/2016/sep/05/philippines-president-rodrigoduterte-barack-obama-son-whore (accessed 26 February 2018).

Gil, Emerlynne (2017) "Public Opinion and the Death Penalty," www.philstar.com (accessed 26 February 2018).

Gita, Ruth Abbey (2017) “Duterte: 'IDon't Care If You Call Me a Killer'," http://www.sunstar.com.ph/manila/ local-news/2017/12/09/duterte-i-dont-care-if-you-call-me-killer-578960 (accessed 26 February 2018).

Gomez, Jim, \& Teresa Cerojano (2017) "Duterte Vows End to Uprising, 'Jail or Hell' in Drug War," http://abcnews.go.com/International/wireStory/major-issues-duterte-confronting-2nd-year48810161 (accessed 26 February 2018). 
Gonzales, Yuji Vincent (2016) "French Paper Banners Duterte as 'Serial Killer President'," http:// globalnation.inquirer.net/146418/french-paper-banners-duterte-as-serial-killer-president (accessed 26 February 2018).

Gutierrez, Filomin (2017) "Duterte and Penal Populism - the Hyper Masculinity of Crime Control in the Philippines," http://discoversociety.org/2017/08/02/focus-duterte-and-penal-populism-thehypermasculinity-of-crime-control-in-the-philippines (accessed 26 February 2018).

Habash, Mohammad (2014) "Countries with Majority Muslim Populations: Islamic Visions for the Abolition of the Death Penalty," in L. Scherdin, ed., Capital Punishment: A Hazard to a Sustainable Criminal Justice System?, Farnham: Ashgate Publishing.

Hagan, John (2003) Justice in the Balkans: Prosecuting War Crimes in the Hague Tribunal, Chicago: University of Chicago Press.

Hagan, John, \& Wenona Rymond-Richmond (2009) Darfur and the Crime of Genocide, Cambridge: Cambridge University Press.

Haidt, Jonathan (2012) The Righteous Mind: Why Good People Are Divided by Politics and Religion, New York: Pantheon.

Heydarian, Richard J. (2018) Duterte's Rise: A Populist Revolt against Elite Democracy, New York: Palgrave Pivot (forthcoming).

Hilbay, Florin T. (2009) "The Philippine President as Tortfeasor-in-Chief: Establishing Civil Liability for Constitutional Negligence." 4 Asian Journal of Comparative Law 1-52.

Hodgkinson, Peter (2004) "Capital Punishment: Improve It or Remove It?" in P. Hodgkinson \& W. Schabas, eds., Capital Punishment: Strategies for Abolition, Cambridge: Cambridge University Press, 1-35.

Honolulu Star-Advertiser (2017) "Withdrawal of Duterte's Threat to Hit Schools Sought," Honolulu Star-Advertiser, 26 July.

Hood, Roger, \& Carolyn Hoyle (2008) The Death Penalty: A Worldwide Perspective, 4th edn, Oxford: Oxford University Press.

Houle, Christian, \& Paul D. Kenny (2018) "The Political and Economic Consequences of Populist Rule in Latin America." 53 Government and Opposition 256-87.

Human Rights Watch (2017) "'License to Kill' Philippine Police Killings in Duterte's 'War on Drugs"”, https://www.hrw.org/report/2017/03/02/license-kill/philippine-police-killings-duterteswar-drugs (accessed 27 February 2018).

Huntington, Samuel P. (2000) "Foreword: Cultures Count," in L. Harrison \& S. Huntington, eds., Culture Matters: How Values Shape Human Progress, New York: Basic Books, xiii-vi.

Inquirer (2017) "The Kill List," http://newsinfo.inquirer.net/794598/kill-list-drugs-duterte (accessed 26 February 2018).

Inzunza, Alejandra Sanchez, \& Jose Luis Pardo Veiras (2017) “A Place Too Used to Death,” New York Times, 16 July.

Iyengar, Rishi (2016) "The Killing Season: Inside Philippine President Rodrigo Duterte's War on Drugs," Time, 10 October.

Johnson, David T., \& Franklin E. Zimring (2009) The Next Frontier: National Development, Political Change, and the Death Penalty in Asia, Oxford: Oxford University Press.

Jones, Clarke (2016) “The Human Cost of Duterte's Drug War," http://www.newmandala.org/humansocial-dimension-dutertes-drug-war/ (accessed 26 February 2018).

Kaiman, Jonathan (2016a) "Meet the Nightcrawlers of Manila: A Night on the Front Lines of the Philippines's War on Drugs," Los Angeles Times, 26 August.

Kaiman, Jonathan (2016b) "The Philippines' Drug Addicts, Shunned by Society and Hunted by Assassins, Find They Have Nowhere to Turn," Los Angeles Times, 16 September.

Kaiman, Jonathan (2017) "In the Philippines, Poverty and Corruption Fuel the Drug Trade," Los Angeles Times, 28 February.

Karnow, Stanley (1989) In Our Image: America's Empire in the Philippines, New York: Random House. Kaufman, Edy, \& Patricia Weiss Fagan (1981) "Extrajudicial Executions: An Insight into the Global Dimensions of a Human Rights Violation." 3 Human Rights Quarterly 81-100.

Kiernan, Ben (2007) Blood and Soil: A World History of Genocide and Extermination from Sparta to Darfur, New Haven: Yale University Press. 
LaFree, Gary (2006) "Expanding Criminology's Domain: The American Society of Criminology 2006 Presidential Address." 45 Criminology 1-31.

Lasco, Gideon (2014) "Pampagilas: Methamphetamine in the Everyday Economic Lives of Underclass Male Youths in a Philippine Port." 25 International Journal of Drug Policy 783-788.

Lasco, Gideon (2016) "Just How Big Is the Drug Problem in the Philippines Anyway?," The Conversation, 13 October.

Lema, Karen (2017) "Son of Philippines' Duterte Linked to \$125 Million Drug Shipment as His Father's Drug War Kills Thousands," http://www.businessinsider.com/r-philippine-presidents-sondenies-links-to-125-million-drug-shipment-2017-9 (accessed 26 February 2018).

Levitsky, Steven, \& Daniel Ziblatt (2018) How Democracies Die, New York: Crown.

Liu, Renwen (2013) "Recent Reforms and Prospects in China," in R. Hood \& S. Deva, eds., Confronting Capital Punishment in Asia: Human Rights, Politics and Public Opinion, Oxford: Oxford University Press, 107-122.

Lubis, Todung Mulya (2014) "Abolition of the Death Penalty: Indonesia at a Crossroads," in L. Scherdin, ed., Capital Punishment: A Hazard to a Sustainable Criminal Justice System?, Farnham: Ashgate Publishing, 251-269.

Luce, Edward (2017) The Retreat of Western Liberalism, New York: Atlantic Monthly Press.

McCargo, Duncan (2016) "Duterte's Mediated Populism." 38 Contemporary Southeast Asia: A Journal of International and Strategic Affairs 185-190.

McCoy, Alfred W. (2009) Policing America's Empire: The United States, the Philippines, and the Rise of the Surveillance State, Madison: University of Wisconsin Press.

McCoy, Alfred W., ed. (1993) An Anarchy of Families: State and Family in the Philippines, Madison: University of Wisconsin Center for Southeast Asian Studies.

Mendez, Christina, \& Edith Regalado (2017) "Rody: Drug War to Be Unrelenting," The Philippine Star, 25 July.

Miller, Lisa L. (2016) The Myth of Mob Rule: Violent Crime and Democratic Politics, New York: Oxford University Press.

Mogato, Manuel, \& Clare Baldwin (2017) "Special Report: Police Describe Kill Rewards, Staged Crime Scenes in Duterte's Drug War," https://www.reuters.com/article/us-philippines-dutertepolice-specialrep/special-report-police-describe-kill-rewards-staged-crime-scenes-in-dutertes-drugwar-idUSKBN17K1F4 (accessed 26 February 2018).

Narag, Raymund E. (2005) Freedom and Death Inside the City Jail, Manila: Supreme Court of the Philippines.

Narag, Raymund E. (2017a) “Crime and Due Process: Is There Room for Dialogue and Compromise?," Rappler, 30 July.

Narag, Raymund E. (2017b) "The Death of Policing as a Profession in the Philippines," Rappler, 19 August.

New York Times (2016) "Slaughter in the Philippines," New York Times, 11 December.

New York Times (2017a) "Court Complaint Accuses Duterte of Mass Murder," New York Times, 24 April.

New York Times (2017b) "Let the World Condemn Duterte," New York Times, 25 April.

Novak, Andrew (2016) The African Challenge to Global Death Penalty Abolition: International Human Rights Norms in Local Perspective, Cambridge: Intersentia.

Packer, Herbert L. (1968) The Limits of the Criminal Sanction, Stanford: Stanford University Press.

Paddock, Richard C. (2017) "Becoming Duterte: The Making of a Philippine Strongman," New York Times, 21 March.

Pamintuan, Ana Marie (2017a) “Are They Dead Yet?," http://www.philstar.com/opinion/2017/07/ 31/1723121/are-they-dead-yet (accessed 26 February 2018).

Pamintuan, Ana Marie (2017b) "Gangster's Paradise," http://www.philstar.com/opinion/2017/08/02/ 1723702/gangsters-paradise (accessed 26 February 2018).

Parreno, Atty Al A. (2011) "Report on the Philippine Extrajudicial Killings, 2001-2010," https://www. asiafoundation.org/resources/pdfs/ReportonPhilippineEJK20012010.pdf (accessed 26 February 2018). 
Philippine Center for Investigative Journalism (2017) "PCIJ Findings: What's Flawed, Fuzzy with Drug War Numbers?," http://pcij.org/stories/pcij-findings-whats-flawed-fuzzy-with-drug-warnumbers (accessed 26 February 2018).

Pinker, Steven (2011) The Better Angels of Our Nature, New York: Viking.

Pratt, John (2007) Penal Populism, London/New York: Routledge.

Rahman, Fifa, \& Nick Crofts (2013) Drug Law Reform in East and Southeast Asia, Lanham: Lexington Books.

Ranada, Pia (2016) “A Look at the State of Crime, Drugs in the Philippines," https://www.rappler.com/ nation/118004-crime-drugs-philippines (accessed 26 February 2018).

Ranada, Pia (2017) "83\% of Filipinos Trust, Approve of Duterte-Pulse Asia," https://www.rappler. com/nation/157545-filipinos-trust-duterte-pulse-asia-survey-december-2016 (accessed 27 February 2018).

Ranada, Pia (2018a) "Duterte Denies Hand in SEC Ruling vs Rappler," https://www.rappler.com/ nation/193764-malacanang-denies-duterte-hand-sec-ruling-rappler (accessed 26 February 2018).

Ranada, Pia (2018b) "Malacanang Wants 'Less Controversial' Tokhang Operations," https://www. rappler.com/nation/194750-malacanang-less-controversial-tokhang-war-drugs-pnp (accessed 26 February 2018).

Rappler (2017) "State of the Nation Speech, Quezon City, Republic of the Philippines," Rappler, 24 July, http://www.rappler.com/nation/176566-full-text-president-rodrigo-duterte-sona-2017philippines (accessed 26 February 2018).

Rauhala, Emily (2016) "Before Duterte Was the Philippines' President, He Was 'The Death Squad Mayor'," Washington Post, 28 September.

Remnick, David (2017) "One Hundred Days," The New Yorker, 1 May.

Reuters Staff (2017) "Philippines Duterte Welcomes Probe into Allegations He Hid Wealth," https:// uk.reuters.com/article/uk-philippines-duterte-probe/philippines-duterte-welcomes-probe-intoallegations-he-hid-wealth-idUKKCN1C21C4 (accessed 26 February 2018).

Roberts, Julian V., Loretta J. Stalans, David Indermaur, \& Mike Hough (2003) Penal Populism and Public Opinion: Lessons from Five Countries, Oxford: Oxford University Press.

Robinson, Paul H., \& Sarah M. Robinson (2018) Shadow Vigilantes: How Distrust in the Justice System Breeds a New Kind of Lawlessness, Amherst: Prometheus Books.

Rodis, Rodel (2017) "Why the General Acceptance of Patriarchal Authoritarian Rule?," http://usa.inquirer.net/5658/general-acceptance-patriarchal-authoritarian-rule (accessed 26 February 2018).

Romero, Alexis (2017) "Duterte Gov't Probing Over 16,000 Drug War-Linked Deaths as Homicide, not EJK," Philippine Star, 27 December.

Santos, Ana P. (2017) “A Philippine Senator Defies Her President," Los Angeles Times, 29 March.

Sarat, Austin (1999) The Killing State: Capital Punishment in Law, Politics, and Culture, Oxford: Oxford University Press.

Savelsberg, Joachim J. (2015) Representing Mass Violence: Conflicting Responses to Human Rights Violations in Darfur, Berkeley: University of California Press.

Savelsberg, Joachim J. (2017) "International Criminal Law as One Response to World Suffering: General Observations and the Case of Darfur," in R. Anderson, ed., Alleviating World Suffering: The Challenge of Negative Quality of Life, Cham: Springer International Publishing, 361-373.

Savelsberg, Joachim J. (2018) "Punitive Turn and Justice Cascade: Mutual Inspiration from Punishment and Society and Human Rights Literatures." 20 Punishment \& Society 73-91.

Schabas, William A. (2002) The Abolition of the Death Penalty in International Law, 3rd edn, Cambridge: Cambridge University Press.

Schabas, William A. (2004) "International Law and the Death Penalty: Reflecting or Promoting Change?," in P. Hodgkinson \& W. Schabas, eds., Capital Punishment: Strategies for Abolition, Cambridge: Cambridge University Press, 36-62.

Sikkink, Kathryn (2011) The Justice Cascade: How Human Rights Prosecutions Are Changing World Politics, New York: W. W. Norton \& Company. 
Simangan, Dahlia (2017) "Is the Philippine War on Drugs an Act of Genocide?" 20 Journal of Genocide Research 68-89.

Simon, Jonathan (2007) Governing through Crime: How the War on Crime Transformed American Democracy and Created a Culture of Fear, Oxford: Oxford University Press.

Smith, Daniel M. (2018) Dynasties and Democracy: The Inherited Incumbency Advantage in Japan, Palo Alto, CA: Stanford University Press.

Special Report (2017) "Introduction and Table of Contents of 'Special Report: The State-Sponsored Extrajudicial Killings in the Philippines'," http://fingfx.thomsonreuters.com/gfx/mkt/2/112/110/ document.pdf (accessed 26 February 2018).

Spierenburg, Pieter (2008) A History of Murder: Personal Violence in Europe from the Middle Ages to the Present, Cambridge: Polity.

Stanton, Gregory H. (2018) "Genocide Watch: The International Alliance to End Genocide," http://www.genocidewatch.org/aboutgenocide/8stagesofgenocide.html (accessed 27 February 2018).

Super, Gail J. (2016) "Punishment, Violence, and Grassroots Democracy in South Africa-the Politics of Populist Punitiveness." 18 Punishment \& Society 325-345.

Syjuco, Miguel (2017) "The Injustice System,” New York Times, 26 April.

Symmes, Patrick (2017) "The List," New York Times Magazine, 15 January.

Talabong, Ramb (2018a) "How the 'New' Oplan Tokhang Should Be Done," https://www.rappler.com/ newsbreak/iq/194687-new-oplan-tokhang-guidelines-pnp-war-drugs (accessed 26 February 2018).

Talabong, Rambo (2018b) "PNP Chief Invites Public to Join Oplan Tokhang," https://www.rappler.com/ nation/194719-pnp-chief-dela-rosa-invites-public-join-oplan-tokhang (accessed 26 February 2018).

The Nation \& AFP (2016) “"Barbaric' Duterte Wants Daily Executions in the Philippines," The Nation \& AFP, 19 December, http://www.nationmultimedia.com/news/breakingnews/30302404 (accessed 26 February 2018).

Tordesillas, Ellen T. (2017) “The Height of Impunity,” http://news.abs-cbn.com/blogs/opinions/07/13/ 17/opinion-the-height-of-impunity (accessed 26 February 2018).

Transparency International (2016) “Corruption Perception Index 2016," https://www.transparency.org/ news/feature/corruption_perceptions_index_2016 (accessed 27 February 2018).

Tree, Sanho (2018) "The War on Drugs Breeds Crafty Traffickers," New York Times, 26 March.

United Nations Office on Drugs and Crime (2014) "World Drug Report 2014," https://www.unodc.org/ documents/wdr2014/World_Drug_Report_2014_web.pdf (accessed 27 February 2018).

United Nations World Drug Report (2012) “World Drug Report 2012," https://www.unodc.org/documents/ data-and-analysis/WDR2012/WDR_2012_web_small.pdf (accessed 27 February 2018).

Villamor, Felipe (2017a) "A Rare Survivor of a Philippine Drug Raid Takes the Police to Court," New York Times, 11 February, https://www.nytimes.com/2017/02/10/world/asia/a-rare-survivor-of-aphilippine-drug-raid-takes-the-police-to-court.html (accessed 26 February 2018).

Villamor, Felipe (2017b) "Ex-Officer in Philippines Says He Led Death Squad at Duterte's Behest," New York Times, 20 February.

Villamor, Felipe (2017c) "Killing of Teenager by Police in Philippines Spurs Thousands to Protest," New York Times, 27 August.

Villamor, Felipe (2017d) "Leila De Lima, Critic of Duterte, Is Arrested in the Philippines," New York Times, 23 February.

Villamor, Felipe (2017e) "Philippine Police Are Accused of Killing South Korean Businessman," New York Times, 19 January, https://www.nytimes.com/2017/01/19/world/asia/philippines-policesouth-korean-killing.html (accessed 26 February 2018).

Villamor, Felipe (2017f) "Philippines Extends Martial Law in Besieged Region," New York Times, 24 July.

Villamor, Felipe (2018a) "Philippines Plans to Withdraw from International Criminal Court," New York Times, 14 March.

Villamor, Felipe (2018b) "International Criminal Court Will Investigate Duterte Over Drug War," New York Times, 8 February.

Villamor, Felipe (2018c) "Murder Charges in Philippine Police Case that Ignited Anger Over Drug War," New York Times, 29 January. 
Weiss, Brennan (2017) "The Lawyers Taking on Duterte Over His 'War on Drugs'," http://www. aljazeera.com/indepth/features/2017/04/lawyers-duterte-war-drugs-170406100150963.html (accessed 26 February 2018).

Whaley, Floyd (2016) "Blueprint for Taming the Philippines," New York Times, 17 June.

Witchel, Elisabeth (2016) "Getting Away with Murder," Committee to Protect Journalists, 27 October.

World Prison Brief (2017) http://www.prisonstudies.org/world-prison-brief-data (accessed 27 February 2018).

Zimring, Franklin E. (2003) The Contradictions of American Capital Punishment, Oxford: Oxford University Press.

Zimring, Franklin E. (2017) When Police Kill, Cambridge, MA: Harvard University Press. 